\title{
Travelers, Strangers, and Jim Crow: Law, Public Accommodations, and Civil Rights in America
}

\author{
A. K. SANDOVAL-STRAUSZ
}

Public accommodations-hotels, trains, restaurants, steamboats, theaters, buses, motels, and the like-were for more than a century located at the epicenter of legal and political struggles for racial equality. From the age of Reconstruction to the civil rights movement of the mid-twentieth century, civil rights in public places stood alongside voting rights, school integration, and equal opportunity in employment and housing as conditions that black people and their allies claimed as necessary attributes of a just society. The Civil Rights Act of 1875 and the Supreme Court rulings in the Civil Rights Cases and especially in Plessy v. Ferguson were critical episodes in the career of Jim Crow in the nineteenth century, followed in the twentieth by the Montgomery bus boycott, the sit-ins, the Freedom Rides, and the Civil Rights Act of 1964. Martin Luther King vividly described the consequences of discrimination in public accommodations in his 1963 "Letter From Birmingham Jail," which conveyed the utter frustration of the moment "when you suddenly find your tongue twisted and your speech stammering as you seek to explain to your six-year-old daughter why she can't go to the public amusement park ... when you take a cross-country drive and find it necessary to sleep night after night in the uncomfortable corners of your automobile because no motel will

A. K. Sandoval-Strausz is an assistant professor of history at the University of New Mexico <aksandov@unm.edu>. He would like to thank Bill Novak, Kathy Conzen, Neil Harris, Barbara Welke, Amy Stanley, Chris Tomlin, Linda Kerber, Sharon Salinger, Tom Brennan, Mae Ngai, and the anonymous referees of Law and History Review for their invaluable help with this article. Thanks also to Kyle Volk for heroic research assistance and especially to Cathleen Cahill for inspiration. 
accept you; when you are humiliated day in and day out by nagging signs reading 'white' and 'colored[..]"'1

Despite the recurrent importance of public accommodations in civil rights history and ongoing scholarly debates over law, rights, and regulation, our historical understanding of this category of space remains incomplete. This article reveals little-known aspects of the common law and contextualizes them within longer trajectories of law and governance in Europe and America, seeking thereby to broaden our legal-historical perspective on the origins and development of civil rights in public places. My argument is made in three parts. First, I assert that the common law of innkeepers played a crucial role in the history of racial segregation in the United States. Because existing scholarship on the subject has been based almost exclusively on the common law of common carriers, however, the larger legal context of both aspects of the common law has been obscured.

My second argument is that claims of civil rights in public accommodations were predicated upon a quiet but powerful strand of Anglo-American law that provided for the protection of travelers. When racially progressive Reconstruction legislators sought to guarantee their black constituents equal access to public places, the entering wedge of their legal and political arguments came from the existing common law privileges of travelers. Legal protections of wayfarers were equally important in the twentieth century, when they served as the keystone of public accommodations laws that remain in effect today. Before the common law could be used in this way, however, its duties and privileges had to be turned into rights, a process that formed a critical episode in the prehistory of civil rights law. ${ }^{2}$

Third, I contend that this new understanding of the common law antecedents of civil rights forces us to rethink traditional narratives of the rise of rights and the trajectory of liberalism in American history. The struggle for civil rights in public places was not simply an elaboration of the Revolutionary rhetoric of rights or a new birth of freedom. It was in fact a recon-

1. Civil Rights Act of 1875, 18 Stat. 335 (1875); Civil Rights Cases, 109 U.S. 3 (1883); Plessy v. Ferguson, 163 U.S. 537 (1896); Civil Rights Act of 1964, 78 Stat. 241 (1964); Martin Luther King, Jr., "Letter From Birmingham Jail," in Why We Can't Wait (New York: Harper \& Row, 1964), 81.

2. Notably, Willard Hurst entertained the idea that the development of the automobile and the corresponding growth of the hotel industry granted "new importance to the law of innkeepers" and made "[d]iscrimination on racial, national, or religious grounds, in serving the traveling public ... a greater problem." See Hurst, "Technology and the Law: The Automobile" (unpublished 1949 manuscript), cited in William J. Novak, "Law, Capitalism, and the Liberal State: The Historical Sociology of James Willard Hurst," Law and History Review 18 (2000): 109-10. Hurst was correct about the hotel and innkeeper law, though as I shall demonstrate, the change had taken place many decades earlier than he supposed. 
figuration of pre-Enlightenment corporative and communitarian privileges into individually possessed entitlements. While this maneuver seemed to provide a solid legal and ideological basis on which to expand the freedom of all Americans, it was soon hobbled by its roots in liberal political theory. It was not until many decades later that civil rights lawyers and the nation's judiciary rehabilitated key features of a centuries-old common law regime in order to outlaw discrimination in public accommodations.

The issues at stake in this article are at once historical, historiographic, and theoretical. The subject derives from a scholarly discussion that began nearly a half-century ago with the publication of C. Vann Woodward's The Strange Career of Jim Crow. ${ }^{3}$ The subsequent decades of intense debate over Woodward's ideas have remained substantially concerned with public accommodations law, especially the customs, statutes, and court cases that preceded the Supreme Court's 1896 Plessy ruling, often seen as the paradigmatic example of the "separate but equal" doctrine that characterized Jim Crow. In one sense, this preoccupation with Plessy is appropriate, both because of its role as a leading case on the constitutionality of segregation laws and because railroads were so influential in nineteenth- and twentieth-century legal development. ${ }^{4}$ In another sense,

3. The "Woodward thesis" stated first, that legally enforced racial segregation did not appear in the South immediately after Emancipation, but rather was imposed only after about 1890; and second, that before this happened, there had been realistic and partially explored historical alternatives to the final outcome of de jure separation of black and white Americans. See C. Vann Woodward, The Strange Career of Jim Crow (New York: Oxford University Press, 1955), chap. 1; Howard N. Rabinowitz, "More than the Woodward Thesis: Assessing The Strange Career of Jim Crow," Journal of American History 75 (1988): 842. For a detailed historiography and extensive bibliography of this debate, see Rabinowitz, 845-50. Key works include Leon F. Litwack, North of Slavery: The Negro in the Free States, 1790-1860 (Chicago: University of Chicago Press, 1961); Richard C. Wade, Slavery in the Cities: The South, 1820-1860 (New York: Oxford University Press, 1964); Joel Williamson, After Slavery: The Negro in South Carolina During Reconstruction, 1861-1877 (Chapel Hill: University of North Carolina Press, 1965); John W. Blassingame, Black New Orleans, 1860-1880 (Chicago: University of Chicago Press, 1973); Howard N. Rabinowitz, Race Relations in the Urban South, 1865-1890 (New York: Oxford University Press, 1978); Edward L. Ayers, The Promise of the New South: Life after Reconstruction (New York: Oxford University Press, 1992).

4. But legal historians increasingly suspect that Plessy's actual jurisprudential importance has been greatly exaggerated: see Stephen J. Riegel, "The Persistent Career of Jim Crow: Lower Federal Courts and the 'Separate but Equal'" Doctrine, 1865-1896," American Journal of Legal History 28 (1984): 18-40; Charles A. Lofgren, The Plessy Case: A Legal-Historical Interpretation (New York: Oxford University Press, 1987); Barbara Young Welke, "When All the Women Were White, and All the Blacks Were Men: Gender, Class, Race, and the Road to Plessy, 1855-1914," Law and History Review 13 (1995): 261-316 and Recasting American Liberty : Gender, Race, Law, and the Railroad Revolution, 1865-1920 (Cambridge: Cambridge University Press, 2001). 
however, the focus on Plessy can create problems insofar as it leads legal scholars to read the case anachronistically back into earlier periods or to overemphasize railroads at the expense of other legally significant spaces. ${ }^{5}$ Incorporating innkeeper law into our account allows us to see more clearly how traditional legal protections of travelers underlay public accommodations and civil rights law. This line of inquiry also revises civil rights historiography by suggesting that an undue emphasis on Jim Crow, defined as legally mandated racial separation, introduces particular ideological biases into our conceptions of justice. At the most general level of social and political theory, this exploration of the fight against racial inequality in public places engages debates over American liberalism and civil society, emphasizing the unexpected persistence of premodern ideas in America by bringing us face to face with an apparent paradox: justice being claimed in the Enlightenment language of rights and equality while remaining logically dependent on an earlier legal regime based explicitly on public welfare, special privilege, and hierarchy. ${ }^{6}$

5. See, for example, Earl M. Maltz, “'Separate but Equal' and the Law of Common Carriers in the Era of the Fourteenth Amendment," Rutgers Law Journal 17 (1986): 553-68; Patricia Hagler Minter, "The Failure of Freedom: Class, Gender, and the Evolution of Segregated Transit Law in the Nineteenth-Century South," Chicago-Kent Law Review 70 (1995): 993-1009; Kenneth W. Mack, "Law, Society, Identity, and the Making of the Jim Crow South," Law and Social Inquiry 24 (1999): 377-409. For an account that all but ignores the common law, see Richard C. Cortner, Civil Rights and Public Accommodations: The Heart of Atlanta and McClung Cases (Lawrence: University Press of Kansas, 2001). On law and space, see Nicholas K. Blomley, Law, Space, and the Geographies of Power (New York: Guilford Press, 1994) and David Delaney, Race, Place and the Law, 1836-1948 (Austin: University of Texas Press, 1998).

6. Key texts in the historical debate over American liberalism include Oscar Handlin and Mary Flug Handlin, Commonwealth: A Study of the Role of Government in the American Economy: Massachusetts, 1774-1861 (Cambridge: Harvard University Press, 1947); Louis Hartz, The Liberal Tradition in America: An Interpretation of American Political Thought Since the Revolution (New York: Harcourt, Brace, 1955); C. B. MacPherson, The Political Theory of Possessive Individualism (Oxford: Clarendon Press, 1962); Bernard Bailyn, The Ideological Origins of the American Revolution (Cambridge: Harvard University Press, 1967); Gordon S. Wood, The Creation of the American Republic, 1776-1787 (Chapel Hill: University of North Carolina Press, 1969); David Brion Davis, The Problem of Slavery in an Age of Revolution, 1770-1832 (Ithaca: Cornell University Press, 1975); Joyce Appleby, Capitalism and a New Social Order: The Republican Vision of the 1790s (New York: New York University Press, 1984) and Liberalism and Republicanism in the Historical Imagination (Cambridge, Mass.: Harvard University Press, 1992); Stephen Skowronek, Building a New American State: The Expansion of National Administrative Capacities, 1877-1920 (Cambridge: Cambridge University Press, 1982); Forrest McDonald, Novus Ordo Seclorum: The Intellectual Origins of the Constitution (Lawrence: University Press of Kansas, 1985); James T. Kloppenberg, "The Virtues of Liberalism: Christianity, Republicanism, and Ethics in Early American Political Discourse," Journal of American History 74 (1987): 9-33 and The Virtues of Liberalism (New York: Oxford University Press, 1998), especially 


\section{Innkeeper Law, the Fourteenth Amendment, and the Civil Rights Act of 1875}

This article will of necessity range back and forth across centuries, but the indispensable starting point is Reconstruction, a period that transformed American life as had none since the Revolution. The emancipation of four million enslaved Americans forced the nation to confront fundamental issues of equality, citizenship, federalism, and rights, precipitating a radical restructuring of governance in the United States. The Fourteenth Amendment was the pivotal document in this transformation because it provided, for the first time in the nation's history, a constitutional guarantee of equality to all citizens. Its stipulation that no state could "abridge the privileges or immunities of citizens" or "deny to any person within its jurisdiction the equal protection of the laws" heralded the dawn of the civil rights era. Black people's desire for equality was by no means new, of course, but now they and all other U.S. citizens had recourse against abuses at the state and local levels by direct appeal to the federal government. In theory, this meant that laws that explicitly discriminated against former slaves and other black people were rendered null and void by authority of the federal government, which directly guaranteed its citizens against such deprivations of liberty and equality. In addition, other, less overt varieties of discrimination could now be attacked directly. ${ }^{7}$

chaps. 3, 4, 8, 9; Daniel T. Rodgers, "Republicanism: The Career of a Concept," Journal of American History 79 (1992): 11-38. For the intersection of this debate with legal history, see especially Christopher Tomlins, Law, Labor, and Ideology in the Early American Republic (Cambridge: Cambridge University Press, 1993); William J. Novak, The People's Welfare: Law and Regulation in Nineteenth-Century America (Chapel Hill: University of North Carolina Press, 1996); Amy Stanley, From Bondage to Contract: Wage Labor, Marriage, and the Market in the Age of Slave Emancipation (Cambridge: Cambridge University Press, 1998). Among political theorists, questions about liberalism are often situated within a larger scholarly debate about civil society. Key works in this literature include John Rawls, A Theory of Justice (Cambridge: Harvard University Press, 1971); Ronald Dworkin, Taking Rights Seriously (Cambridge: Harvard University Press, 1977); Michael J. Sandel, Liberalism and the Limits of Justice (Cambridge: Cambridge University Press, 1982); Michael Walzer, Spheres of Justice (New York: Basic Books, 1983); Alisdair MacIntyre, After Virtue (South Bend: University of Notre Dame Press, 1984); Jürgen Habermas, Moral Consciousness and Communicative Action, trans. Christian Lenhardt and Shierry Weber Nicholson (Cambridge: MIT Press, 1990); Jean L. Cohen and Andrew Arato, Civil Society and Political Theory (Cambridge: MIT Press, 1994); John Gray, Enlightenment's Wake: Politics and Culture at the Close of the Modern Age (New York: Routledge, 1995).

7. Eric Foner, Reconstruction: America's Unfinished Revolution, 1863-1877 (New York: Harper \& Row, 1988), xxiii-xxiv, 602-12, and generally; Foner, The Story of American Freedom (New York: Norton, 1998), 95-113; Alfred H. Kelly, Winfred A. Harbison, and 
From the moment of its ratification in 1868, the Fourteenth Amendment was used as a legal basis for securing equal access to public accommodations. Black communities in cities like Louisville and Savannah staged nonviolent demonstrations in an effort to integrate public transportation, and black legislators in Southern states introduced bills requiring equal rights in public houses and on conveyances. While such efforts initially met with defeat, the rising influence of black elected officials in the South translated into increasing success for civil rights statutes after 1870. Texas led the way in 1871 with a law prohibiting railroads from "making any distinction in the carrying of passengers," followed by Florida, Louisiana, Mississippi, South Carolina, and Arkansas, which in 1873 enacted statutes threatening the proprietors of public accommodations with fines, imprisonment, and revocation of licenses if they practiced "discrimination on account of race or color" or otherwise denied any customers "the same accommodations as are furnished other persons." Community pressure and state legislation did result in a few high-profile legal judgments and did in some cases improve black access to public places, particularly in the urban South. More common, however, was massive nonenforcement by local officials and frequent refusals by state courts to find in favor of black plaintiffs, who were left without further legal recourse. ${ }^{8}$

The constant obstruction of antidiscrimination laws at the state level set the stage for federal civil rights legislation. The bill that would become the Civil Rights Act of 1875 was first introduced in 1870 by Massachusetts Senator Charles Sumner, the senior Radical Republican in Congress and a staunch ally of black Americans both during slavery and after emancipation. The first draft of the Act contemplated not simply a public accommodations law, but also a broadly drawn statute prohibiting race-based discrimination in a wide variety of civic institutions, including "theaters or other places of public amusement . . . common schools and other public institutions of learning ... church organizations, cemetery associations, and benevolent institutions." Under the proposed law, a person who had

Herman Belz, The American Constitution: Its Origins and Development (New York: Norton, 1991), 319-61; Robert J. Kaczorowski, The Politics of Judicial Interpretation: The Federal Courts, Department of Justice, and Civil Rights, 1866-1876 (Dobbs Ferry, N.Y.: Oceana, 1985); William E. Nelson, The Fourteenth Amendment: From Political Principle to Judicial Doctrine (Cambridge: Harvard University Press, 1988); Akhil Reed Amar, The Bill of Rights: Creation and Reconstruction (New Haven: Yale University Press, 2000).

8. Foner, Reconstruction, 368-72; Charles Vincent, Black Legislators in Louisiana during Reconstruction (Baton Rouge: Louisiana State University Press, 1976), 92-97; Woodward, Strange Career, 27-28; The Revised Statute Laws of the State of Louisiana (New Orleans: Bloomfield \& Co., 1876), 128-29, 441-43; A Digest of the Statutes of Arkansas (Little Rock: Little Rock Print. \& Pub., 1874), 257-60. 
been discriminated against could bring the accused proprietor or official before a federal judge and upon conviction could collect a fine of $\$ 500$; further fines, imprisonment, and loss of license or charter would also be imposed upon the guilty party. The Act drew its authority from the Fourteenth Amendment's requirement of equal protection and its allowance for direct federal jurisdiction in cases involving abridgement of citizens' rights. The Fourteenth Amendment had explicitly outlawed the kind of active and official racial discrimination epitomized by the Black Codes. The Civil Rights Act was designed to accomplish the much more ambitious goal of putting an end to passive and private forms of discrimination. ${ }^{9}$

This was a far more formidable task, however, and presented specific legal difficulties. It was in the process of overcoming these difficulties that very particular aspects of the common law became the pivot upon which the entire Civil Rights Act turned. The sponsors of the bill realized that it had a potential weak point: the wording of the Fourteenth Amendment was that "no State" would be allowed to violate citizens' rights or deny them legal equality. Opponents of the bill might therefore argue that it was unconstitutional because it operated on individuals and groups rather than states; on their reading, any activity that was not undertaken directly by a state government or its officers was immune to intervention by the federal government. The supporters of the Act thus had to persuade their colleagues in Congress that public accommodations and all the other objects of the law were inherently linked to the states in which they were located. ${ }^{10}$

It is here that the significance of innkeeper law starts to become apparent. When the legislators behind the civil rights bill sought to establish a connection between seemingly private institutions and state governments, they invoked particular kinds of establishments, usually in a particular order. In a formulation that was repeated time and again, they first cited inns, then carriers, and then analogized to other kinds of public space. The legal basis for this connection was that accommodations and means

9. Congressional Globe, 41st Congress, 2nd Session, 13 May 1870, 3434; Congressional Globe, 42nd Congress, 1st Session, 9 March 1871, 21; Congressional Globe, 42nd Congress, 2nd Session, 20 December 1871, 244. Note that there had been an earlier federal enactment, the Civil Rights Act of 1866, but its requirement of equal protection had been made a part of the Constitution with the passage of the Fourteenth Amendment. Alfred Avins's "The Civil Rights Act of 1875: Some Reflected Light on the Fourteenth Amendment and Public Accommodations," Columbia Law Review 66 (1964): 873-915, provides a useful overview of the Congressional debates over the Act, though Avins was apparently writing in opposition to the Civil Rights Act of 1964.

10. The issue of state action under the Fourteenth Amendment was raised because apart from "common schools and other public institutions of learning," which were unmistakably state institutions, other establishments covered by the proposed civil rights bill were technically privately owned concerns. 
of transportation corresponded to two closely related categories in AngloAmerican common law: innkeepers and common carriers. Establishments that fell under these rubrics had a determinate legal status and a special relationship to state governments. Supporters of the Act thus sought to establish its legitimacy by using deeply rooted traditions of governance as the leading edge of expansive rights claims under the proposed law. ${ }^{11}$

In Congress, speakers referred constantly to inns, hotels, trains, steamboats, and other accommodations and conveyances. Sumner opened the Senate debate by asserting that "a legal institution, anything created or regulated by law ... must be opened equally to all without distinction of color." By way of example, he noted: "Notoriously, the hotel is a legal institution, originally established by the common law, subject to minute provisions and regulations; notoriously, public conveyances are in the nature of common carriers subject to law of their own." He then drew analogies to theaters, schools, and cemeteries. Indeed, Sumner pointed out, "inns or public conveyances" had been the legal "prototypes" for "[t]heaters and other places of public amusement," and he reiterated that all such places must therefore be available to all: "As the inn cannot close its doors, or the public conveyance refuse a seat to any paying traveler, decent in condition, so must it be with the theater and other places of public amusement." Senator Frederick Frelinghuysen of New Jersey put particular emphasis on inns, using them in an almost incantatory fashion by referring time and again in a single speech to "inns, places of public amusement, schools," "inns, places of amusement, and public conveyances" (three times), "inns, public conveyances, and places of amusement, common schools, institutions of learning and benevolence, and cemeteries," and "inns, \&c." The same arguments were made in the House of Representatives. Congressman Benjamin F. Butler reminded his fellow legislators of certain rights shared by all: "Every man has a right to go into a public inn. Every man has a right to go into any place of public amusement or entertainment ... any line of stagecoaches, railroad, or other means of public carriage[.]" From there, he moved on to cemeteries, charitable institutions, and schools. Robert B. Elliott, a black lawyer representing South Carolina, emphasized personal and collective experience alongside legal argument when he spoke of "the evils of which we complain, our exclusion from the public inn, from the saloon and table of the steamboat, from the sleeping-coach on the railway,

11. This is not to suggest that inns preceded carriers each and every time they were mentioned. In some cases this order was reversed, including in the first draft of the proposed Act. But once the debate began in earnest and the wording of the Act was changed on 18 January 1872 to mention inns before carriers (the form in which it was finally enacted), Sumner and other supporters of the bill gave precedence to the law of innkeepers. Congressional Globe, 42nd Congress, 2nd Session, 22 January 1872, 487. 
from the right of sepulture in the public burial-ground[.]" Other lawmakers who made speeches in support of the Act repeated these formulations. ${ }^{12}$

This particular ordering of institutions raises questions about the relative position of innkeepers and common carriers in nineteenth-century American law. Because they had shared legal roots and similar provisions, it is not clear why one so frequently preceded the other in carefully crafted legal arguments set forth by sophisticated and experienced lawyer-legislators. (Sumner was knowledgeable enough about the common law of inns and carriers to have edited a treatise on the law of bailments, and Butler chaired the House Judiciary Committee and had been the plaintiff's attorney in two important public accommodations cases in antebellum Boston.) The historical memories of those involved offer little help: a hotel's attempt to eject Frederick Douglass from its dining room in 1853 had been a widely publicized incident in antislavery circles, but protests against discrimination on streetcars and railroads in the 1850s and 1860s were probably more easily remembered. The phrasing may simply have repeated that used in older sources written before the age of railroads, when inns were a more conspicuous everyday presence than carriers: in the works of the century's leading jurists, innkeepers were dealt with before common carriers, which were in turn explained with reference to inns. ${ }^{13}$

More important than their respective statuses, though, is what can be learned by analyzing innkeeper and common carrier law in tandem. Such an approach enables us to understand what underlay both bodies of com-

12. Congressional Globe, 42nd Congress, 1st Session, 20 December 1871, 242; Congressional Globe, 42nd Congress, 2nd Session, 15 January 1872, 381-85; Congressional Record, 43rd Congress, 1st Session, 29 April 1874, 3452-53; Congressional Record, 43rd Congress, 1st Session, 19 December 1873, 340 (Vol. 2, Pt. 1); Congressional Record, 43rd Congress, 1st Session, 6 January 1874, 408 (Vol. 2, Pt. 1). For further examples, see Congressional Globe, 42nd Congress, 2nd Session, 6 February 1872, 843-44; Congressional Record, 43rd Congress, 1st Session, 6 January 1874, 423-24, 427 (Vol. 2, Pt. 1).

13. Joseph Story, Commentaries on the Law of Bailments (Boston: Little and Brown, 1851); McCrea v. Marsh, 78 Mass. 211 (1858) and Burton v. Scherpf, 83 Mass. 133 (1861), pleadings for which are kept at the Social Law Library, Boston; Julia Griffiths, ed., Autographs for Freedom (Auburn, N.Y.: Alden, Beardsley, 1854); James Kent, Commentaries on American Law (New York: O. Halsted, 1827), 2:464; Joseph Story, Commentaries on the Law of Bailments (Cambridge, Mass.: Hilliard and Brown, 1832), chap. vi, art. vii. With the advent of the steam locomotive, however, common carrier law grew in importance within American jurisprudence: the 1851 edition of Story's Bailments retained the same ordering and references as the 1832 edition, but two later treatises diverged in this respect: Isaac Redfield's The Law of Carriers of Goods and Passengers ... [and] the Responsibility and Duty of Innkeepers (Cambridge, Mass.: Houghton \& Co., 1869) dealt with innkeepers toward the end of the volume, while Isaac Edwards's A Treatise on the Law of Bailments (New York: Banks \& Bros., 1878) maintained the older sequence, though without the customary description of carriers in terms of innkeepers. 
mon law-to determine why these legal structures existed, what ideological commitments and intellectual currents lay behind them, and how they could be taken up and deployed in new contexts. I deal with these questions in detail below, but the main idea is that these common law rules existed for the benefit of travelers, a group that enjoyed special privileges in Atlantic and Mediterranean societies. Exploring the origins and development of travel law reveals the ironies, contradictions, and unintended consequences that characterized the legal construction of space in America.

These ideas in turn underscore the basic issue at the heart of this article: the legal status of the traveler and its centrality to the history of civil rights in America. It was with good reason that racially progressive Reconstruction legislators chose to support the Civil Rights Act by citing the traditional legal protections of travelers - it allowed them to establish a legal precedent for civil rights for black people without having to directly confront the emotionally explosive and politically treacherous issue of racial equality. At a time when most white Americans, even most Unionists and Republicans, bridled at the very idea that blacks were or could ever be their true equals, it was politically expedient to couch demands for civil rights in terms of a category of protection that was both nonracial and a long-established fact of everyday life for millions of Americans. This tactic was no more than an artifact of 1870 s politics, yet it had enduring consequences-for as it turned out, the legal linkage of travel and civil rights established the juridical and ideological terrain on which a century of struggles would take place. ${ }^{14}$

\section{Protecting Travelers}

The protection of travelers was an imperative with many expressions in American law. It was not a formal body of law like marriage and admiralty, defined by treatises and indexed in reference works. Rather, it was manifested in a number of different areas, including rules applying to public houses, conveyances, liquor licensing, and Sabbath observance. Innkeeper law provided the most detailed and comprehensive expression of these travelers' protections. Moreover it revealed key features that were not readily apprehended within the context of the law of common carriers. More important than the distinctions among various aspects of travel law, however, were their commonalities. Underlying all common law protections of travelers was a basic assumption: people who were on a journey,

14. Foner, Reconstruction, 369, 497-99, 525-28. 
away from their home communities and in unfamiliar surroundings, were particularly vulnerable and therefore deserved a special legal status. ${ }^{15}$

There were three basic components of innkeeper law, customarily condensed into the phrase "bed, board, and hearth." The first common law duty of innkeepers was to provide any available accommodation ("bed") to any traveler willing to pay a reasonable price. Innkeepers were not at liberty, in other words, to pick and choose their clientele, accepting some as guests while turning others away. (This rule was not absolute: innkeepers could establish reasonable rules for the behavior of guests and thus exclude, for example, known criminals, people who were drunk and disorderly, or those with contagious diseases; if a judge deemed such rules unreasonable, however, the publican could be sued or prosecuted.) The Massachusetts statutes of 1786, for example, stipulated that any innkeeper "convicted of refusing to make suitable provision when desired, for the receiving of strangers, travellers, and their horses and cattle" would "be deprived of his or her license" and thereby put out of business. In addition, courts enforced the duties of innkeepers even in the absence of such statutes. Common law practice was that an innkeeper's refusal to admit a guest gave that person the right to sue the innholder for any resultant damages. For example, if a traveler's goods were stolen or damaged by

15. On the common law, see Morton J. Horwitz, "The Conservative Tradition in the Writing of American Legal History," American Journal of Legal History 17 (1973): 275 and especially The Transformation of American Law, 1780-1860 (Cambridge: Harvard University Press, 1977), 1-30; James R. Stoner, Jr., Common Law and Liberal Theory: Coke, Hobbes, and the Origins of American Constitutionalism (Lawrence: University Press of Kansas, 1992); Oliver Wendell Holmes, Jr., The Common Law (Boston: Little, Brown, 1881), Part III; See also the legal treatises cited below, as well as Century Digest, Cases to 1896, v. 2, under "Innkeepers" (St. Paul: West Publishing Co., 1911). My contention that the status of the traveler is the fundamental consideration behind these aspects of the common law puts me into disagreement with Joseph William Singer, who has argued that it is the fact of their being public callings that requires inns, carriers, and other establishments to serve all comers. In refuting the role of travel, he states: "If the importance of the right to travel is the basis for placing a duty to serve on inns and common carriers, then surely the duty should extend to businesses that sell food and clothing." In fact, the eighteenth- and nineteenth-century statutes I have cited did often apply to people who sold provisions, then called victuallers. Regarding clothiers, the scarcity of retail clothing stores until relatively recently makes it difficult to come to meaningful conclusions about their status in early America. Notably, the argument that stores partook of the same legal status as inns was in fact deployed by opponents of federal civil rights enforcement in the 1870s: see Appendix to the Congressional Globe, 42nd Congress, 2nd Session, 6 February 1872, 28-29 (Pt. 6). I agree with Singer's normative argument and recognize the existence of public callings, but the historical record indicates that travelers and strangers did indeed have a special status. See "No Right to Exclude: Public Accommodations and Private Property," Northwestern University Law Review 90 (1996): 1283-1497, especially 1446. 
rain because an innkeeper refused to offer shelter, that innkeeper would have to pay the traveler at least the full value of the loss. Innkeepers were thus compelled by two separate sets of regulation-the public law of the state and the private law of damages on suit_-to serve the public without discriminating among guests. In this way the early American law of travel sought to ensure that all innkeepers fulfilled the primary purpose of the inn as a shelter for travelers. ${ }^{16}$

The second common law responsibility of the innkeeper was to provide guests with food and refreshment ("board"). This rule corresponded to the secondary characteristic that defined inns, taverns, and hotels-their exclusive privilege of selling alcoholic drinks for consumption on the premises. The basic quid pro quo of innkeeping was that the opportunity to enter the profitable business of bartending was granted in exchange for a proprietor's promise to accommodate the traveling public. But because the regulation of alcohol was one of the most important preoccupations of early American governance, and especially because innkeepers often abused their privileges and neglected the needs of wayfarers, additional laws were passed for the protection of travelers. States typically regulated innkeepers' provision of sustenance. Vermont, for instance, required that

16. For an introduction to innkeeper law, see David S. Bogen, "The Innkeeper's Tale: The Legal Development of a Public Calling," Utah Law Review 51 (1996): 51-92; General Laws of Massachusetts to 1822 (Boston: Wells \& Lilly, 1823), 299; Story, Commentaries on the Law of Bailments, chap. vi, art. vii, §§470-77. Some states referred to the common duties of the innkeeper and provided public penalties for their contravention without naming them specifically, as in The Public Statute Laws of the State of Connecticut (Hartford: Hudson \& Goodwin, 1808), 640-42. See also Public Acts of the General Assembly of North Carolina (Newbern: Martin \& Ogden, 1804), 2:122; Marbury \& Crawford's Digest of Laws of Georgia (Philadelphia: R. Aitken, 1800), 453-54. For historical background on inns and taverns, see David W. Conroy, In Public Houses: Drink and the Revolution of Authority in Colonial Massachusetts (Chapel Hill: University of North Carolina Press, 1992); Peter Thompson, Rum Punch \& Revolution: Taverngoing \& Public Life in Eighteenth-Century Philadelphia (Philadelphia: University of Pennsylvania Press, 1999); Sharon V. Salinger, Taverns and Drinking in Early America (Baltimore: Johns Hopkins University Press, 2002); Kym S. Rice, Early American Taverns: For the Entertainment of Friends and Strangers (Chicago: Regnery Gateway, 1983). Innkeepers were not, however, at liberty to exclude people whose illness was not a danger to other guests and whose removal might result in damage to their health. See Gilbert v. Hoffman, 66 Iowa 205 (1885) and McHugh v. Schlosser, 159 Pa. 480 (1894). Generally speaking, nineteenth-century courts gradually reduced innkeepers' discretion over their premises even as they granted railroads broadened prerogative to control their operations. See John P. Hankey and A. K. Sandoval-Strausz, "The Entrepreneurial Redefinition of Space: Hotels and Railroads in Antebellum America," paper delivered at "The Next Social History?" conference, Franke Institute for the Humanities, 1998 and the Decennial Digest, Century Edition (St. Paul: West Publishing, 1902), under "Carriers" and "Innkeepers." 
they "at all times be furnished with suitable refreshments, provisions, and accommodations for travellers, their cattle and horses[.]" In addition, state governments often set maximum prices for food and drink in order to protect travelers from overcharging. The welfare of travelers was considered so important, in fact, that they were exempted from existing laws prohibiting the purchase of alcohol on the Sabbath. A Maine law employed language seen in numerous other statutes when it prohibited innkeepers from selling alcohol on Sunday, but made an exception for sales to "travellers, strangers, or lodgers in such houses[.]" These laws and many others like them made clear the intention of the authorities to ensure that travelers were properly provided for, protected from extortion, and left unobstructed on their journeys. ${ }^{17}$

The third obligation of the innkeeper was to safeguard the property of guests (that is, to offer them a metaphorical "hearth"). If any of a traveler's possessions or goods was lost or stolen while at an inn, the keeper was presumed responsible and would be compelled to compensate the guest for the full value of the loss. As with the first two rules, the purpose of the third was to provide protection to travelers who might be victimized, in this case by innkeepers colluding with local thieves. The influential American jurist Chancellor James Kent explained: "Travellers, who must be numerous in a rich and commercial country, are obliged to rely almost implicitly on the good faith of innkeepers; and it would be almost impossible for them, in any given case, to make out proof of fraud or negligence in the landlord." The innkeeper's liability was in fact so strict that he was answerable not only for the acts or negligence of his servants, but also those of other guests or any unidentified party. While this was indeed a heavy burden of responsibility, Joseph Story, the leading treatise-writer in nineteenth-century America, defended the rule on the grounds that the vulnerability of the traveler created "an extraordinary temptation to fraud" and a "danger of plunder," which required a "policy of subjecting particular classes of persons to extraordinary responsibility." Indeed, the imperative of protecting the traveler was so powerful that innkeepers were to be presumed guilty of all thefts on their premises, even though such a

17. On linkage of liquor and accommodation, see A Collection of All Such Acts of the General Assembly of Virginia ... (Richmond: S. Pleasants, 1814), 284-87, and General Laws of Pennsylvania 1700-1849 (Philadelphia: Johnson, 1849), 598; The Laws of Vermont to 1824 (Windsor: Simeon Ide, 1825), 483, and see also Commonwealth v. Shortridge, 6 Marsh. 631 (1830); Novak, The People's Welfare, 92; State v. Wynne, 8 N. C. 451 (1821). On price-setting, see also The Laws of Maryland (Baltimore: Nicklin \& Co., 1811), 1:392; Laws of the State of Maine (Portland: Thos. Todd, 1834), 75, 698. On Sabbath exception, see also General Laws of Massachusetts, 407, and Digest of Laws of Georgia, 481. 
stance conflicted with Anglo-American law's traditional presumption of innocence. ${ }^{18}$

It is essential to understand, however-particularly in light of the pivotal role of common law precedents in the debates over the Civil Rights Act of 1875 - that these were not "rights" in any proper sense of the term. The law of innkeepers and other legal regimes of travel were neither individual entitlements nor narrowly economistic protections of commerce, nor were they derived from modern market-based ideas about monopoly. Rather, they were part of what William Novak has described as an American tradition of well-regulated society based not upon property, minimal government, and individual rights, but rather on community, public authority, and the common good. This mode of governance was fundamentally social. People were understood as being constituted through their relations with others in the community; individuality was hardly erased, but it was defined within society, not in opposition to it. Any claim of unrestrained individual prerogative was therefore inherently attached to a person's duties or obligations to others. The sum of these duties outweighed personal privilege, and in any contest of "rights," those of the whole community superseded those of any person or group. Laws constituted an active and collective effort by the citizenry to preserve public order and promote the welfare of its members. This common law notion of a well-regulated society is not reducible to republicanism, utilitarianism, liberalism, or any other unitary paradigm or conflict between paradigms, though it certainly shares some of their assumptions and values. I emphasize its distinctive character precisely to highlight the importance of common law protections of travelers in securing what we now understand as civil rights and to discourage the tendency to read these protections ahistorically as simply a hidden or incipient rights regime expressed in archaic legal language. ${ }^{19}$

The texts, application, and origins of innkeeper law all attest to its place within this tradition of the well-regulated society. In statute after statute, the common law heritage is expressed through references to public necessity and the common good. Innkeeping is defined not simply as a private business pursued by a profit-seeking individual, but as a public calling subject at all points to regulation by the community. Like practically all other states, Massachusetts restricted entry into the trade, imposing limits upon who could do business and granting licenses for only as many inns

18. Kent, Commentaries, 2:592-97; Story, Bailments, chap. vi, art. vii, §464. These treatise-writers also noted that while the presumption of guilt in English common law was related to the low repute in which innkeepers were held, the higher social status of American hosts, who were as often as not the equals of their guests, did not serve to lessen the burdens placed on innkeepers at law.

19. Novak, The People's Welfare, 19-50 and generally. 
as were "necessary for the public good." By the same token, Connecticut permitted the issuance of additional tavern permits only when town selectmen "shall judge it to be of public convenience and necessity," and Pennsylvania allowed innkeepers to operate only if their premises really were "necessary to accommodate the public and entertain strangers or travellers." The doctrine that an inn was a distinctly public institution was expressed time and again in legal sources which underscored the belief that the private interests of innkeepers had to be subordinated to the common good. Chancellor Kent, for example, justified the heavy legal obligations placed upon innkeepers as "founded on the principle of public utility, to which all private considerations ought to yield." These repeated expressions of concern for the public good were not simply idle or ornamental-they represented serious intellectual and jurisprudential commitments. Then, as now, lawyers and judges chose their words with extreme care because they knew their phrasings would be parsed for their precise meaning when the time came for application and enforcement. ${ }^{20}$

Furthermore, the privileges of the traveler were regularly withheld from entire classes of people - an ironic fact, given their eventual use in support of civil rights. Many state innkeeper codes included provisions like the Maryland statute that forbade innkeepers to "harbour, entertain, or sell liquor to, any indentured apprentice ... servant, or slave" without the written consent of the individual's "master, mistress, or owner," and courts regularly ruled that the presence of even free black patrons alongside whites was grounds for ordering an inn closed. In addition, in some regions, innkeepers were expected to notify local magistrates of the arrival of outsiders so that indigents could be asked to leave lest they become a burden on the community. These examples in themselves are perhaps not fully probative evidence, since dependents of all kinds were regularly excluded from such emoluments of citizenship as voting, making contracts, serving on juries, and pursuing certain professions. Yet these were not the only Americans with limited access to inns, for the fact was that even propertied white men could be barred from the inns in their own towns. Since inns were intended for travelers, local inhabitants did not enjoy the same privileges in them. The preamble to a colonial-era New York licensing law avowed that "the original Design of instituting Inns and Taverns was that Travellers might be accommodated with Necessaries and Conveniences," but lamented that this goal had been "perverted to the most mischievous Purposes in society[.]"

20. Laws of Massachusetts, 298; Laws of the State of Connecticut, 640; Laws of Pennsylvania, 598. Nor was public oversight of inns purely restrictive: the state of New York actively encouraged the maintenance of inns in remote yet important locations by easing licensing requirements for establishments that were rarely visited but were "nevertheless of public utility." See Laws of the Colony of New York (Albany: Lyon, 1888-), 11th Session, 710; Kent, Commentaries, 2:460. 
Some states placed restrictions upon local residents' use of taverns. New Hampshire specified that "no taverner shall suffer any of the inhabitants of the town or place ... to remain in his house after nine of the clock in the evening," and Connecticut not only mandated the exclusion of "tavernhaunters," it also barred every innkeeper from "suffer[ing] any inhabitant of such town where he dwells" to "sit drinking or tippling ... above the space of one hour at a time[.]" Such divisions of inn patrons into groups with differing status demonstrates that the provisions of innkeeper law were distinctly situational: travelers enjoyed privileges and innkeepers bore obligations, but nobody possessed automatic entitlements. (These important distinctions are not easily recognized in common carrier law because all carrier patrons were by definition travelers and thus entitled to protection. $)^{21}$

But the strongest evidence that the protection of travelers was not a rights-based regime comes from political genealogy and simple chronology. The origins of the law of innkeepers and that of common carriers are found not in the natural rights tradition of the Enlightenment, but rather in classical antiquity and with the monarchical state. The earliest textual evidence of these legal formulations comes from sixth-century Rome, though the rules involved had probably been observed for centuries before. The Digest, an authoritative law code that the emperor Justinian ordered compiled in 530 C.E., confirmed the basic terms of the protection of travelers by specifying that "an innkeeper or liveryman is not regarded as choosing his own traveler and cannot refuse those making a journey" and by making ships' masters, innkeepers, and stablekeepers answerable for all losses of their guests' property. The success of the Roman imperial project disseminated these legal principles throughout Europe and Asia Minor, and they often remained in effect long after the collapse of the Empire. They persisted through the early medieval period and were still being enforced by English common law judges in the fourteenth through the seventeenth centuries. With the rise of royal autocracy and the elaboration of new theories of sovereigns' plenary police power, these same basic principles were adapted to the monarchist legal regimes of modern Europe: Nicolas Delamare's enormously influential Traité de la Police (1722) and William Blackstone's canonical Commentaries on the Laws of England (1765-69)

21. Laws of Maryland, 396, and see also Laws of Pennsylvania, 600; Salinger, Taverns and Drinking, 21-24, 121-50, 230-39; Josiah Henry Benton, Warning Out in New England (Boston: W. B. Clarke, 1911); “The Diary of Robert Love,” P-363 of the Pre-Revolutionary War Diaries at the Massachusetts Historical Society; Charles Z. Lincoln, The Colonial Laws of New York from the Year 1664 to the Revolution (Albany: J. B. Lyon, 1894), 100; Laws of the State of New-Hampshire (Exeter: Norris \& Co., 1815), 373, and Laws of the State of Connecticut, 641-42. 
both contained detailed expositions and justifications of the special status of travelers. The protections of travelers that operated in eighteenth-century North America marked the colonists' adoption of premodern legal regimes that had existed for centuries before the emergence of Enlightenmentinspired ideas of individuality and rights. In sum, the worlds that created and re-created innkeeper and common carrier law were hardly a credible seedbed for ideas about universal entitlement. ${ }^{22}$

\section{The Transformation of Innkeeper Law}

How could it be, then, that laws characterized by communalism and special privilege became the basis for claims of individual rights belonging equally to all? The answer is that common law protections of travelers were themselves transformed years before being deployed on behalf of black Americans. Over the course of several decades around the middle of the nineteenth century, state and federal judges modified the legal status of the traveler by recasting its situational privileges as inherent rights. Innkeeper law changed in two closely related ways: first, its protections were broadened to apply not just to travelers, but to the general public; second, they were redefined as individually possessed entitlements. These changes were by no means made in the name of equality, and the subsequent application of innkeeper law to the struggle for civil rights was almost certainly unintended. The transformation of this body of law also created opportunities for innkeepers to evade their traditional responsibilities by claiming a right to property in their establishments. These new claims would have crucial ramifications for the way civil rights in public accommodations were asserted-and resisted.

The transformation of innkeeper law was the result of interrelated changes in the material landscape and ideological environment of nineteenth-century America. The intensification and expansion of commerce, fostered by a transportation revolution driven by new technologies like the steamboat

22. For the ancient Roman and medieval English origins of innkeeper law, see David S. Bogen, "Ignoring History: The Liability of Ships' Masters, Innkeepers and Stablekeepers under Roman Law," American Journal of Legal History 36 (1992): 326-60 and Bogen, "The Innkeeper's Tale," 55-62; Bernhard Bischoff and Michael Lapidge, eds., Biblical Commentaries from the Canterbury School of Theodore and Hadrian (Cambridge: Cambridge University Press, 1994), 415; Story, Bailments, chap. vi, art. vii, §467; Nicolas Delamare, Traité de la Police (Paris, 1722), cited in Thomas E. Brennan, Public Drinking and Popular Culture in Eighteenth-Century Paris (Princeton: Princeton University Press, 1988), 277; William Blackstone, Commentaries on the Laws of England (Oxford: Clarendon Press, 1765-1769), 1:13.402 and 14.417-18, 2:30.451, 3:9.164, 4:13.168. 
and locomotive, gave rise to a massive upsurge in the number of people moving from place to place. The need to accommodate so many travelers caused small, individually held inns and taverns to be gradually replaced by large, corporately owned, professionally managed hotels. Beginning in the 1830s, hotels became leading centers of business activity, sociability, and politics in communities throughout the nation, and hotelkeepers increasingly included restaurants, barbershops, ticket offices, tobacconists, and similar service establishments on their premises; hotelkeepers also welcomed women, who had typically been excluded from inns and taverns except as servers or sex objects. The everyday use of hotels and their amenities in turn generated new expectations that the general public was welcome in hotels and other public houses and that most people should have easy access to them. These assumptions were very much in keeping with the contemporaneous rise of Jacksonian political ideology, which generally supported the expansion of white men's access to such key institutions as the electoral franchise, the ownership of land, and business incorporation. Meanwhile, within American jurisprudence, the tradition of the well-regulated society was beginning to come under pressure from the gathering influence of classical liberalism, with its market-driven emphasis on individualism and property and corresponding tendency to define the public good as simply an aggregate of private interests. The combination of customary protections and possessive individualism in an age of expanding claims to the emoluments of citizenship opened the possibility of a corresponding expansion in the definition of who could legitimately claim the privileges of the traveler. ${ }^{23}$

23. George Rogers Taylor, The Transportation Revolution, 1815-1860 (New York: M. E. Sharpe, 1951), 15-103; A. K. Sandoval-Strausz, "For the Accommodation of Strangers: Urban Space, Travel, Law, the Market, and Modernity at the American Hotel, 1789-1908" (Ph.D. diss., University of Chicago, 2002), chaps. 1, 2, 4; Arthur M. Schlesinger, Jr., The Age of Jackson (Boston: Little, Brown, 1945); Harry L. Watson, Liberty and Power: The Politics of Jacksonian America (New York: Hill and Wang, 1990); Daniel Feller, The Jacksonian Promise: America, 1815-1840 (Baltimore: Johns Hopkins University Press, 1995); Horwitz, Transformation of American Law, 1780-1860; Tomlins, Law, Labor, and Ideology; Novak, The People's Welfare. Some scholars, most notably Charles Sellers in The Market Revolution: Jacksonian America, 1815-1846 (New York: Oxford University Press, 1991), have attributed all these changes to the rapid penetration of capitalism into various spheres of everyday life. While I agree that market relations were transformative in this period, such arguments, when drawn too briefly or broadly, lose their explanatory force and obfuscate rather than elucidate; for this reason I have chosen to avoid elaborating such an argument in this article. For commentary on the promise and problems of theories of market revolution, see Melvyn Stokes and Stephen Conway, eds., The Market Revolution in America: Social, Political, and Religious Expressions, 1800-1880 (Charlottesville: University Press of Virginia, 1996) and Daniel Feller, "The Market Revolution Ate My Homework," Reviews in American History 25 (1997): 408-15. 
The tension between the traditional interpretation of innkeeper law and the liberalized formulation that increasingly supplanted it was evident in attorneys' arguments and judges' verdicts. Among the earliest authoritative cases was Markham v. Brown. It arose out of an 1835 altercation in a New Hampshire tavern in which Brown, the operator of a new stagecoach line, sought to solicit customers in the parlor of Markham's establishment. When Markham forbade Brown to do so because of the tavernkeeper's previous arrangements with other stagecoach lines, the two ended up in court. Markham's lawyers cited the traditional understanding of the innkeeper's obligations, correctly quoting the "ancient strictness" of the English common law, which stated that "none but travellers have a right in a common inn[.]" The New Hampshire Supreme Court disagreed, however, reasoning that since an innkeeper was bound to receive travelers, "he may likewise be held, under such proper limitations, to admit those who have business with them as such." The ruling was a marked departure from English authorities because rather than limiting the customary special legal status to travelers, it expanded it to a broader range of people. It by no means declared a general entitlement, but did represent a significant and novel extension of legal protection beyond those who were away from home. Markham v. Brown became the most cited innkeeper case in United States courts as the nation's judiciary continued to broaden the reach of the protections of innkeeper law. ${ }^{24}$

Within twenty years, American judges were close to establishing a general entitlement to accommodation. In State v. Whitby (1854), the Delaware Supreme Court declared a sweeping right of access. "All persons have the right to go to an inn, as guests, or for the purpose of selling any thing," the justices announced, and added furthermore that a guest had "a right to remain there so long as he behaves himself peaceably and properly, he paying for the entertainment." Subsequent cases involving the "board" and "hearth" provisions guaranteeing food and refreshment and the protection of patrons' belongings echoed this doctrine by severing or at least weakening the traditional connection between travel and protection. "Distance is not material," held a Connecticut court. "A townsman or neighbor may be a traveler and therefore a guest at an inn as well as he who comes from a distance[.]" The authoritative case law on common carriers, while less

24. Markham v. Brown, 8 N. H. 523 (1837), 525-26, 529. It is worth noting that the English common law did not expand privileges in an inn beyond travelers themselves. See, for example, Holder v. Soulby, 8 C.B. 254 (1860), 256; The Queen v. Rymer, 2 Q.B.D. 136 (1877); Lamond v. Richard and the Gordon Hotels, Limited, 1 Q.B. 541 (1897). 
comprehensive than the law of innkeepers before about 1880, suggests a similar tendency toward an expanding right of carriage..$^{25}$

The language that judges employed in their rulings on innkeeper cases provides further evidence of the changing assumptions behind the legal protection of travelers. The vocabulary of the well-regulated society was gradually but unmistakably being supplanted by the terminology of classical liberalism. Early nineteenth-century cases tended to employ words connoting relations of responsibility and privilege: innkeepers were deemed "chargeable," "liable," or "answerable" for the losses of their guests, and patrons received "license" or "permission" to enter inns. Toward the end of the 1830s, and more noticeably after the 1840s, judges were inclined to use a more individualistic idiom of possession and entitlement. The ruling in Markham v. Brown typified this trend. The justices declared a "right of the traveller" where once there had only been an assigned privilege. The same tendency was evident in State v. Whitby, in which the "right to go to an inn" was proclaimed without reference to reciprocal duties or special conditions. These new linguistic conventions precisely tracked the legal content of the rulings, leaving little doubt that they constituted a meaningful textual reflection of new ways of thinking about the law. ${ }^{26}$

25. State v. Whitby, 5 Har. (Del.) 494 (1854). For the leading case law on the duties of "board" and "hearth," see Mason v. Thompson, 9 Pick. (Mass.) 280 (1830); Wintermute v. Clarke, 5 Sandf. (N.Y.) 242 (1851); Walling v. Potter, 35 Conn. 183 (1868). Note that the extension of travelers' protections to local residents was often contested, as in Thickstun $v$. Howard, 8 Blackf. (Ind.) 535 (1847); Ingalsbee v. Wood, 33 N.Y. 577 (1865). On common carrier law, see Jencks v. Coleman, 2 Sumn. (Mass.) 221 (1835); Bennett v. Dutton, 10 N.H. 481 (1839); Wheeler v. San Francisco \& A. R. Co., 31 Cal. 46 (1866); Tarbell v. Central Pacific R. Co., 34 Cal. 616 (1868); Pittsburgh, C. \& St. L. Ry. Co. v. Vandyne, 57 Ind. 576 (1877); Brown v. Memphis \& C. R. Co., 5 Fed. 499 (1880); Brown v. Memphis \& C. R. Co., 7 Fed 51 (1881); Atwater v. Delaware, L. \& W. R. Co., 48 N.J. Law 55 (1886). The federal cases indicate that courts increasingly scrutinized the exclusion of women on the basis of "reputation for chastity." On the relative development of innkeeper and common carrier law, see their respective sections in the American Digest, Century Edition (St. Paul: West Publishing, 1902). The severing of the relationship between travel and liquor retailing is perhaps most unequivocally demonstrated by the rise of the saloon, a drinking establishment that lacked any apparent connection to the accommodation of wayfarers. Notably, late nineteenth-century efforts to control public drinking sometimes involved the reimposition of older standards, as with the 1896 Raines Law's requirement that some saloonkeepers maintain beds on the premises. See Perry Duis, The Saloon: Public Drinking in Chicago and Boston, 1880-1920 (Urbana: University of Illinois Press, 1983); Madelon Powers, Faces along the Bar: Lore and Order in the Workingman's Saloon, 1870-1920 (Chicago: University of Chicago Press, 1998); Kenneth T. Jackson, ed., The Encyclopedia of New York City (New Haven: Yale University Press, 1995) 984-85.

26. See, for example, Adams v. Freeman, 12 Johnson (N.Y.) 408 (1816), an apparent outlier on the restriction of privileges to travelers; Mason v. Thompson; Markham v. Brown, 527; State v. Whitby, 496; Walling v. Potter, 185; Atwater v. Sawyer, 76 Me. 538 (1884). The path of innkeeper 
The liberal reformulation of innkeeper law also opened the door to a countervailing set of claims made not by inn patrons, but by proprietors. Faced with a clientele that was increasingly successful in expanding its prerogatives, innkeepers sought to reassert control by claiming rights based on their property in their establishments. In place of the traditional regulatory regime grounded in the common law vision of the public good and the power of the state to protect travelers, innkeepers hoped to promulgate a new paradigm involving a sort of balancing test of conflicting rights to the space of the inn. The Pennsylvania Supreme Court's 1850 ruling in Commonwealth v. Mitchel was an explicit articulation of this effort. The situation was essentially the same as in Markham v. Brown. Mitchel, the keeper of the United States Hotel in Philadelphia, had "for personal reasons" forbidden a Mr. Potter to enter the establishment again. When Potter returned some days later, Mitchel laid a hand on Potter's shoulder to lead him out and found himself accused of assault. When the case came to trial, the court took a highly unorthodox approach to the matter. Rather than focusing on the protection of travelers, the justices reasoned outward from what they called "the rights of the proprietor of a hotel, as to the control of his own house, and of those who enter it." They declared that a hotelkeeper "has undoubtedly the same control over his dwelling that anyone else has" and stated that "if he pleases, he can refuse to admit any one," though the keeper would still be liable for civil damages in a private suit. "Any other rule," reasoned the court, "would expose all well regulated public houses to the constant intrusions of the idle, dissolute and abandoned in the community." 27

Commonwealth v. Mitchel preserved the essential feature of the relationship between host and guest by allowing the innkeeper to be sued by the person he turned away. At the same time, however, it pointed the way

law necessarily relates to ongoing debates regarding the persistence of the "well-regulated society" described by William Novak as opposed to the countervailing idea of a capitalist-friendly "transformation of American law" proposed by Morton Horwitz. My research suggests that a legal order based on protection and obligation was quite durable. The cases I have cited sometimes involved travelers winning judgments that were so enormous as to threaten even a large hotel with bankruptcy; given the importance of hotels in transportation networks and national expansion, this can hardly be seen as economically "efficient." Indeed, my findings extend Novak's world even further into the present than he himself would, since I see some aspects of the well-regulated society persisting deep into the twentieth century. That said, the judicial language I have just cited also suggests that the protections of innkeeper law, however persistent they were, were also being reinterpreted in ways that could be considered liberal as early as the 1830s; this liberal reformulation resulted in the same rulings as had been rendered before, but there can be little doubt that the assumptions behind them were in flux in Jacksonian America.

27. Commonwealth v. Mitchel, 1 Phila. (Pa.) 426 (1850), 436, 439-40. 
to a reconfiguration along privatistic lines, illustrating perfectly how the logic of liberalism exerted pressure on innkeeper law. The Pennsylvania court displayed considerable fidelity to the common law ideal of an ordered society: it decreed that all inns must be "well regulated," invoked "community," and saw the poor and outcast as the main threat to these, a clear endorsement of inequality-based social stability. But the justices were clearly persuaded by liberal social theory in their willingness to put private property rights ("the rights of the proprietor ... to the control of his own house") at the heart of their legal reasoning. Congruent with this new logic was the judges' preferred method of enforcement, which relied not on public authority, but instead on market-oriented private remedies that the court believed would prevent abusive behavior by innkeepers. "The interests and future success in business of the hotel keepers," reasoned the court, "combined with the great competition in this occupation, is a sufficient guarantee for a polite and accommodating spirit," making public penalties like the revocation of licenses unnecessary. Such reliance on private law to regulate innkeepers' behavior could scarcely have been more different from the public statutory regimes previously enacted by states and communities, based as they were on a sense of public good that regularly trumped both individual entitlements and property holdings. While this liberalized version of innkeeper regulation was still merely a tendency within law at midcentury, it was gaining in influence. Ultimately it would sound the death knell of the Civil Rights Act of 1875 and bedevil civil rights efforts for decades thereafter. ${ }^{28}$

\section{The Contested Legacy of the Civil Rights Act of 1875}

The consequences of this conflict over legal interpretation became apparent as Congress debated the Civil Rights Act. The arguments corresponded exactly to the two competing versions of innkeeper law, recapitulating opposing assertions of public authority and private prerogative. Supporters of the proposed Act mobilized the common law vision of a well-regulated society in order to establish an intimate connection between public accommodations and state government and thereby to legitimate federal antidiscrimination efforts. The bill's opponents parried by invoking the liberal shibboleths of private property rights and the need to limit the state's regulatory authority. In so doing they made clear just how sharp the double edge of rights discourse could be. In Senate debate in 1871, for example, Ohio Democrat Allen Thurman attacked the bill for ignoring

28. Ibid., 426, 440-42. 
the all-important boundary between the action of state governments and the private status of proprietors. "It makes every tavern-keeper the State in which he lives," declared Thurman, "every manager of a theater the State in which he lives; every conductor of a railroad the State in which he lives." But these were not public institutions, he reasoned, and the mere fact of common law traditions was not sufficient to make such establishments into government agencies. Similar objections were raised by a Connecticut Republican who protested against what he saw as illegal usurpation of state sovereignty, and by a Georgia senator who rather hyperbolically suggested that the proposed Act "invited to these halls ... the [Paris] commune ... the international," making it "the most dangerous precedent that has ever been set by this legislative body." Identical objections based on assertions of federal tyranny and property rights were subsequently raised in the House of Representatives. ${ }^{29}$

The stakes of this conflict of legal theories were raised even higher by opponents of civil rights enforcement who attacked the common law itself. The idea that public authority must in some cases be limited by property rights was not new. But some lawmakers amplified it into a radical departure from traditional norms of governance by proposing that a regime based on private property and self-interest should entirely replace active governmental efforts to protect travelers and promote the general welfare. In their view, the common law was a rightful casualty of competitive capitalism. Senator William Hamilton, a Maryland Democrat, stated flatly: "So far as I am concerned, in reference to inns, I would brush away all the old common-law notions that attached to them hundreds of years ago ... [this] is a thing of the past." No such rules were necessary because the well-being of travelers would be automatically and ably protected by the invisible hand of the market. "Competition is the ruling spirit everywhere," asserted Hamilton, "and innkeepers and hotelkeepers now are only too anxious to get guests." It cannot be known for certain whether Hamilton truly believed that the profit motive would afford black people equal access to public accommodations; the prevalence of racial exclusion in his native state must have suggested otherwise. But from the point of view of white supremacy, the benefit of laissez-faire arguments was precisely that they made it possible to defend discrimination with high-sounding theoretical language. A sure sign that legislators in the Reconstruction-

29. Congressional Globe, 42nd Congress, 2nd Session, 21 December 1871, 279-80; Congressional Globe, 42nd Congress, 2nd Session, 8 February 1872, 892-93 and 9 February 1872, 928. On the House of Representatives, see, for example, Congressional Record, 43rd Congress, 1st Session, 5-6 January 1874, 375-82, 405-6, 417-22, 427-30 (Vol. 2, Part 1); Appendix to the Congressional Record, 43rd Congress, 1st Session, 29 May 1874, 341-44 (Vol. 2, Part 6). 
era South had recognized and understood the egalitarian potential of the common law came when Tennessee abolished and Delaware modified the common law of innkeepers and common carriers so that they could not be used by black people to secure equal treatment. This was not the last time that the language of classical liberalism and the abrogation of common law protections would be used to defend white racial privilege. ${ }^{30}$

Objections notwithstanding, the Civil Rights Act passed Congress by substantial margins and became law on March 1, 1875. Black Americans moved decisively to claim the rights it guaranteed them, immediately initiating coordinated actions that began in the South and rapidly spread nationwide. On the day after the Act took effect, several black residents of Richmond methodically entered "various restaurants, including the bar room at the Exchange Hotel, and in one instance a barber shop, and demanded to be waited on." Three days later in Wilmington, North Carolina, a saloon customer demanded that a barkeep be arrested for refusing to serve him. The following week, a black couple in New Orleans tried to sit in a stateroom on a Mississippi River steamboat. On March 19, two theatergoers asked to be seated in the all-white dress circle of McVickers Theater in Chicago. The following month, the New York Times reported that a black man and his companion had tried to integrate the parquet of Booth's Theatre in Manhattan. That summer, similar efforts were undertaken in Galveston, Texas, Winona, Minnesota, and San Francisco, California, and similar scenes followed for years thereafter across the United States. Such acts met with tremendous resistance. Proprietors initially decided on outright defiance of the Act, and when that failed, many preferred to close or surrender their liquor licenses rather than comply with the law. Claims under the Civil Rights Act were so frequent and so avidly pursued and resisted that by 1880 , the United States Attorney General's office reported that despite their best efforts to clear their dockets, federal appeals courts still had a backlog of no fewer than 158 cases. ${ }^{31}$

The escalating conflict over the Act's constitutionality drove the issue of federal civil rights protection inexorably toward the nation's highest

30. Appendix to the Congressional Record, 43rd Congress, 1st Session, 22 May 1874, 363 (Vol. 2, Part 6). A similar tactic was used by a Congressman from New Jersey who attacked the civil rights bill by claiming that the common law regulation of inns had only been justified by past government monopolies; but since that "foundation which once existed, but which for years has been torn away ... we cannot therefore burden their business with any restrictions[.]" See Congressional Record, 43rd Congress, 2nd Session, 4 February 1875, 1001-2; Acts of the 39th Tennessee General Assembly, 1st Session (1875), 216-17; Revised Statutes of the State of Delaware (Wilmington: Mercantile Printing, 1893), 440 (Ch. 194, Vol. 15, passed 25 March 1875).

31. John Hope Franklin, "The Enforcement of the Civil Rights Act of 1875," Prologue (1974): 226-28; Riegel, "Persistent Career," 23. 
court. In the Civil Rights Cases of 1883, the Supreme Court addressed five separate lawsuits brought under the Act (two of them involving denials of service by inns or hotels, two by theaters, and one by a railroad), which had been bundled together for a single adjudication. In so doing, it revisited yet again the conflict between common law and possessive-individualist renderings of the rights and obligations of travelers and proprietors. By that time, however, the newer vision had gained greater currency among American judges. The Supreme Court's verdict adopted precisely the same legal logic that had undergirded both Commonwealth v. Mitchel and the objections to the Act proffered during debates in Congress. An eight-member majority of the justices ruled the Civil Rights Act unconstitutional on the grounds that the Fourteenth Amendment only applied to "State action of a particular character," while discrimination in public accommodations was a private matter, an "[i]ndividual invasion of individual rights." The Court thus abandoned a centuries-old belief that the protection of travelers was a public responsibility that demanded the active involvement of government. In its stead, the majority established the doctrine that the proprietors of inns and other public accommodations were simply private citizens, a legal status that protected them from federal prosecution. "The wrongful act of an individual," reasoned the justices, "is simply a private wrong, or a crime of that individual," rather than an offense against the public good. In legal terms, the ruling signaled the ascendance of individualism and property rights in American jurisprudence. In human terms, it meant the willing abandonment of black people to state and local authorities who could once again deny their claims of equality in public places; it also meant that such denials, no matter how systematic, were declared beyond the ability of the federal government to remedy. This position did not go unchallenged. In his famous dissent, Justice Harlan championed the older common law understanding of inns, carriers, and other public accommodations. Bitterly condemning the "narrow and artificial grounds" of the majority opinion, he sustained the view that "innkeepers are a sort of public servants" whose employment was of a "public nature," and cited major precedents defining railroads as "established by public authority, intended for the public use and benefit." But this common law vision of the public good was no longer so important to American law as it once had been, and Harlan found himself in a minority of one. ${ }^{32}$

32. Franklin, "Enforcement," 233-35; Civil Rights Cases, 11, 17, 26, 38-41. Indeed, the justices went so far as to deny that it was even possible for an individual to deprive a fellow citizen of his or her rights, whether through violence, fraud, or deception. Such actions, they reasoned, must be provided with remedies at the state level. Beyond its formalism, this position also reflected a remarkable indifference to the plight of black people, whom the majority famously remarked must cease "to be the special favorite of the law" (at 25). 
The invalidation of the Civil Rights Act of 1875 permanently halted efforts by Congress to ensure equality in public accommodations on the basis of the Constitution's guarantee of equal protection under law. ${ }^{33}$ Yet this did not mean the end of common law standards of protection or active governmental antidiscrimination efforts. The Civil Rights Cases elicited a forceful response at the state level. Within two years of the ruling, eleven state legislatures in the North and West passed civil rights statutes of their own, and by century's end, a total of eighteen states had mandated racial equality in public accommodations..$^{34}$ Lawmakers in these states explicitly embraced the common law tradition by modeling their statutes on the now-defunct federal act. The New Jersey law, for example, prohibited discrimination in "inns, public conveyances on land or water, theaters and other places of public amusement[.]" Other state laws specified a greater variety of establishments, but these generally were ordered in such a way as to preserve the customary sequence of inns, carriers, and other public accommodations. In keeping with the preliberal origins of the common law, the legal grounding of these statutes was derived not from statements about fundamental equality, but rather from the plenary authority of states to protect the health, safety, and morals of their residents - the same form of power behind longstanding protections of travelers. Notably, when the language of rights was used in lawsuits arising from state civil rights acts, it was as often as not used by the managers of hotels or theaters who claimed a right to protect their property by excluding whomsoever they pleased..$^{35}$

33. Strictly speaking, the ruling in the Civil Rights Cases did not declare the entire Act unconstitutional, since it did not pass on its application to transportation on navigable waters. This question was taken up only in 1913 in Butts v. Merchants \& Miners Transportation Company, 230 U.S. 126 (1913).

34. These were: Connecticut, Iowa, New Jersey, and Ohio (1884), Colorado, Illinois, Indiana, Michigan, Minnesota, Nebraska, and Rhode Island (1885), Pennsylvania (1887), Washington (1890), Wisconsin (1895), and California (1897); Massachusetts, New York, and Kansas already had such laws on the books, but updated them in the aftermath of the Supreme Court ruling. See Milton R. Konvitz and Theodore Leskes, A Century of Civil Rights (New York: Columbia University Press, 1962), 155-59.

35. For details of state laws, see Compiled Statutes of New Jersey (Newark: Soney \& Sage, 1911), 1442; Annotated Statutes of the State of Illinois (Chicago: Callaghan \& Co., 1896), chap. 38, II 82; Revised Statutes of the State of Indiana (Chicago: E. B. Myers, 1888), § 1291a. See also Revised Statutes of Colorado (Denver: Smith-Brooks, 1908), \$609; Annotated Code of the State of Iowa (Des Moines: F. R. Conaway, 1897), § 5008; Compiled Laws of the State of Michigan (Lansing: Robert Smith, 1897), 3495; Annotated Revised Statutes of the State of Ohio (Cincinnati: W. H. Anderson, 1898), §4426-1. For a close analysis of the application of the Illinois Civil Rights Act of 1885, see Elizabeth Dale, "Social Equality Does Not Exist among Themselves, nor among Us: Baylies v. Curry and Civil Rights in Chicago," American Historical Review 102 (April 1997): 311-39. 
In the South, the end of federal civil rights oversight and the establishment of white-supremacist Redeemer governments after the collapse of Reconstruction portended new configurations of race and space. Proprietors and managers reclaimed discretion over whether and how to serve black people and operated their establishments as they saw fit, subject only to such conditions as might be imposed by local judges and juries. As a result, for a period of years black access to public accommodations was uneven and unpredictable, neither required nor prohibited by law, and varying not just by state and county, but often by the whims of individual clerks and conductors. ${ }^{36}$ The subsequent move toward legally required segregation was in fact precipitated by the creation of a new legal regime involving transportation and travel. The law establishing the Interstate Commerce Commission (ICC) — a new federal agency charged with regulating railroad and other transportation across state lines and nationwide-included a provision that might allow black travelers to bring federal authority to bear on discrimination in transportation facilities. In response to what they saw as an incendiary combination of racial egalitarianism and federal intrusion, state legislatures throughout the South began to mandate the separation of passengers by race. This set up yet another clash of federal and state authority in the South, as black travelers demanded that the ICC sustain their claims to equal treatment by overruling state segregation laws. The Supreme Court resolved this conflict of laws in favor of states by ruling in 1890 that state segregation laws could be applied to travelers within a state without contravening federal regulations regarding interstate commerce. A flurry of legislative activity followed, and by the time Plessy $v$. Ferguson came before the Court, all but three states in the South required segregation in railroad transportation. Laws applying to other kinds of public space followed, and by 1901, state laws mandated segregation in practically every area of life throughout the South. Black litigants continued to appeal to the ICC to guarantee that they be treated equally, and while they did win a few cases, for the most part the federal commerce power proved no match for local enforcement of segregation. ${ }^{37}$ Whether

36. Minter, "The Failure of Freedom"; Mack, "Making of the Jim Crow South"; Ayers, Promise of the New South, 136-46; on efforts specifically to control black mobility, $150-52$.

37. Welke, Recasting American Liberty, chap. 9, esp. 343-48, 358-64. Faced with the prospective logistical difficulties of rearranging seats and staterooms at every state line and river port, most railroad and steamboat companies ultimately decided to maintain racial segregation as a matter of privately enforced company policy along routes that passed through the South. Railroads regularly challenged state segregation laws in court in an effort to establish their authority over their operations, but interestingly, they seem to have abandoned a promising line of litigation by not appealing the Mississippi Supreme Court's ruling in Southern Railway Company v. Norton, 112 Miss. 302 (1916). See Welke, 374. 
sustained by custom, instituted by proprietors, or required by state law, discrimination against black people in public places was left unchecked by federal authority for three quarters of a century. ${ }^{38}$

\section{Protecting Black Travelers}

When the long struggle against racial discrimination finally gained momentum in the civil rights movement of the mid-twentieth century, the imperative of protecting travelers again played a crucial role. It was no accident that black activists and their allies focused so much attention on institutions that served travelers. This allowed them once again to mobilize legal regimes of travel so as to translate demands for equality into judicial and legislative action. This strategy incorporated both traditional common law regimes and the federal government's authority to regulate commerce. The commerce power had subsequently been redefined and augmented during the Progressive Era and the New Deal to address the problems of a national industrial economy and used to reduce food contamination, combat child labor, and regulate farms and factories. When lawsuits and demonstrations by black Americans finally forced the United States government to apply this species of authority to the issue of civil rights, the commerce power became a new means by which nineteenth-century protections of travelers were federalized and extended to all Americans in all categories of public space in the twentieth century. Yet this effort involved serious internal ideological conflicts, for while protesters themselves consistently spoke the liberal language of equality and rights and adopted these values as protest ideals, many of their goals could be achieved only by redefining and redeploying premodern regimes of privilege, protection, and police power. ${ }^{39}$

38. C. Vann Woodward, Origins of the New South, 1877-1913 (Baton Rouge: Louisiana State University Press, 1951), 210-12; Foner, Reconstruction, 587-98; Lofgren, The Plessy Case, 20-27; Rabinowitz, Race Relations, 182-97. See also Michael Perman, The Road to Redemption: Southern Politics, 1869-1879 (Chapel Hill: University of North Carolina Press, 1984); Ayers, Promise of the New South.

39. On the expansion of federal regulatory authority, see Gabriel Kolko, The Triumph of Conservatism: A Reinterpretation of American History, 1900-1916 (New York: Free Press, 1963); Thomas K. McCraw, "Regulation in America: A Review Article," Business History Review 49 (1975): 159-83; McCraw, Prophets of Regulation (Cambridge: Belknap Press of Harvard University, 1984); McCraw, ed., Regulation in Perspective: Historical Essays (Cambridge: Harvard University Press, 1981); Skowronek, Building a New American State; Morton Keller, Regulating a New Economy: Public Policy and Economic Change in America, 1900-1933 (Cambridge: Harvard University Press, 1990); William J. Novak, "The Legal Origins of the Modern American State," American Bar Foundation Working Paper \#9925 (1999); G. Edward White, The Constitution and the New Deal (Cambridge: Harvard University Press, 2000). 
It was in cases involving segregated travel that black litigants won their first sustained victories against Jim Crow. In 1937, Congressman Arthur Mitchell of Illinois was ejected from a Pullman railroad car in Arkansas. Taking up a line of legal argument that had been all but abandoned almost fifty years before, he filed a complaint with the ICC. Mitchell gained the support of the Roosevelt administration and in 1941 won a unanimous ruling from the Supreme Court stating that it was unconstitutional to refuse blacks such facilities as were available to other passengers in interstate travel. In 1945, the Court heard Morgan v. Virginia, the suit of a Maryland resident named Irene Morgan who had been arrested and fined for refusing to give up her seat on a Greyhound bus in Virginia in accordance with the state's segregation laws. It ruled Virginia's law unconstitutional when applied to interstate buses, stating that the United States must have "a single, uniform rule to promote and protect national travel," and that this was the purview of a federal government that could prohibit discrimination in interstate transit. In Henderson v. United States (1950), the Court ruled unanimously that racially segregated dining car facilities contravened federal laws governing interstate commerce. Notably, these verdicts avoided equal-protection arguments based on the Fourteenth Amendment, depending instead upon federal powers that had been established to deal with issues relating to travel. ${ }^{40}$

The pace of change quickened in the mid-1950s. The ruling in Brown v. Board of Education signaled the Supreme Court's willingness to uphold direct and sweeping legal challenges to Jim Crow. But the Court's 1954 decision did not mean the end of segregation. As many recent histories of the civil rights movement have demonstrated, even the most authoritative verdicts were routinely ignored at the local level and usually required direct action by black activists to have any real effect. Brown did, however, establish an important legal precedent concerning state-run institutions and

40. Mitchell v. United States, 313 U.S. 80 (1941); Morgan v. Virginia, 328 U.S. 373 (1946); Henderson v. United States, 339 U.S. 816 (1950). There had been two earlier legal victories in lawsuits brought by the NAACP and other private plaintiffs - in Nixon v. Herndon (1927) and Missouri ex rel. Gaines v. Canada (1938)—but the earlier ruling was subsequently repudiated by the Court in Grovey v. Townsend (1935) in a temporary retreat from receptivity to the grievances of black plaintiffs and the latter did not threaten the doctrine of separate but equal. See Kelly, Harbison, and Belz, The American Constitution, 583-85, 591-94; Catherine A. Barnes, Journey from Jim Crow: The Desegregation of Southern Transit (New York: Columbia University Press, 1983), 20-34, 44-51, 71-80; Donald R. McCoy and Richard T. Ruetten, Quest and Response: Minority Rights and the Truman Administration (Lawrence: University Press of Kansas, 1973), 10. In recognizing the continuities between nineteenth- and twentieth-century antidiscrimination law, it is important to note, first, that Mitchell was not the first time that American courts had upheld equality in transportation under the ICC; and second, that the Court recognized this, its verdict in Morgan citing key nineteenth-century rulings involving interstate transportation. See the text of the rulings and Welke, Recasting American Liberty, 358-75. 
provided grounds for further rights claims. Meanwhile, the Montgomery bus boycott of 1955-56 (the local origins of which predated Brown) marked the expansion of earlier challenges to Jim Crow transportation and their extension into the realm of local travel. The boycott succeeded not only in desegregating public transit in the city, it also prompted the ICC to issue a general order prohibiting racial segregation in all modes of interstate transportation. ${ }^{41}$

These developments ushered in a new phase in the civil rights struggle, one in which the boundaries between public and private, and between local and interstate, became key sites of action. Litigation and demonstrations had led to important legal victories, but these had only been possible because they involved institutions over which the federal government had a solid claim to jurisdiction. Brown had depended upon the schools involved being clearly public, state-sponsored institutions subject to Fourteenth Amendment requirements of equal treatment. A similar public status applied to city buses in Montgomery. Interstate buses and other means of transport that crossed state lines might be privately owned, but were subject to federal regulation through the ICC. Yet there were many spaces that were more difficult to desegregate because they were both private and local. Segregationists recognized this and initiated a wave of privatization intended to shift the struggle onto more favorable legal terrain. Southern state legislatures passed bills creating private academies in place of public schools, and counties and municipalities hastily transferred public facilities like buses, parks, and swimming pools to private hands so as to hide behind the state action doctrine established in the Civil Rights Cases of 1883. Only a few years after it had been resurrected as a force for equality, the Fourteenth Amendment seemed to have reached its limits. These new circumstances required a new legal strategy. ${ }^{42}$

41. Brown v. Board of Education of Topeka, Kansas, 349 U.S. 294 (1954). For an excellent review of the historiography of the effect of Brown, see Michael J. Klarman, "How Brown Changed Race Relations: The Backlash Thesis," Journal of American History 81 (1994): 81-118; John Dittmer, Local People: The Struggle for Civil Rights in Mississippi (Urbana: University of Illinois Press, 1994), 41-69; J. Mills Thornton III, Dividing Lines: Municipal Politics and the Struggle for Civil Rights in Montgomery, Birmingham, and Selma (Tuscaloosa: University of Alabama Press, 2002), 20-140, especially 47 on the relationship between the boycott and the Brown decision.

42. Many efforts at segregation through privatization were recognized for what they were by the courts and disallowed, but establishments that had not been public previously seemed impervious to further federal action. Woodward, Strange Career, 158-59; Barnes, Journey from Jim Crow, 101-56; William H. Chafe, Civilities and Civil Rights: Greensboro, North Carolina and the Black Struggle for Freedom (New York: Oxford University Press, 1980), 65-82; Thornton, Dividing Lines, 101-9, 222-25, 254-59; Dittmer, Local People, 43-44, 59. See also Numan V. Bartley, The Rise of Massive Resistance: Race and Politics in the South during the 1950s (Baton Rouge: Louisiana State University Press, 1999). 
In developing this strategy, civil rights lawyers turned to common law protections of travelers. In 1959, Jack Greenberg, soon to be general counsel of the NAACP Legal Defense Fund, published a book in which he described the state of American civil rights law and suggested future approaches to desegregation. Greenberg turned first to public accommodations, observing that most discrimination in such places was private and noting the difficulties presented by the state action doctrine. Yet there were other legal possibilities, since "some common law doctrines deserve attention in connection with public accommodations," particularly the duties of innkeepers and common carriers. Greenberg paid particular attention to the law of innkeepers in a detailed analysis of a century's worth of English and American cases and treatises; significantly, this included a reference to the nineteenth-century transformation of U.S. innkeeper law. The relationship between premodern legal regimes and contemporary civil rights law was explicit: Greenberg explained that innkeeper law had been "developed to protect the traveler in a day when the solitary inn between cities was a necessity on long, dangerous journeys" and observed that "in states where Negroes may expect to be turned away from all places reserved for whites, their position rather closely approximates that of the old English traveler: food, shelter, and protection are hard to come by." The distant past was clearly in play in the mid-twentieth-century present. ${ }^{43}$

Greenberg was not alone in seeing the law of innkeepers and common carriers as crucial to the struggle for equality: the legislatures of many Southern states reached the same conclusion. Recognizing that the traditional duty to serve all could be used to require equal treatment of black people in public accommodations, segregationist legislators took measures to neutralize the threat by statutorily altering the common law. In 1953, Delaware allowed proprietors of inns, restaurants, and similar establishments to refuse service to people whose presence they thought would be offensive to other customers or might otherwise threaten their business. Louisiana in 1954 repealed an earlier law requiring innkeepers to serve all members of the public. Repeating its action of eighty years before, Tennessee in 1955 reaffirmed the abrogation of the common law obligation to accept all comers. The following year, Mississippi granted any person operating a "public business" the right to select patrons. In 1958, Florida decreed that all public lodging and food establishments were private, giving their owners the right to turn away customers as they saw fit. In 1959, Alabama repealed the state code's incorporation of innkeeper law. That same year, Arkansas effectively trumped the common law by threatening "any person who shall enter [a] public business and create disturbance or

43. Jack Greenberg, Race Relations and American Law (New York: Columbia University Press, 1959), 81-87, 96-101. 
breach of peace in any way whatsoever" with a fine of up to $\$ 500$, six months' imprisonment, or both. ${ }^{44}$

The state action doctrine and the rush to privatize space in the South made it clear that real equality would, as it had in the 1870s, require federal intervention. The Kennedy administration, however, mindful of its narrow margin of victory in the 1960 election and its dependence upon white southern votes, was very reluctant to act. The impetus for further efforts again came from black activists and their allies. The growing involvement of students in the civil rights movement in the early 1960s fostered new, more assertive acts of civil disobedience and direct action, most notably sit-ins at lunch counters, hotels, libraries, courthouses, and other public places, and Freedom Rides that tested the court-ordered desegregation of travel facilities. The responses of southern whites ranged from attempts to humiliate demonstrators at restaurants to the bloody riots and attempted murders that greeted Freedom Riders in Alabama and were threatened in Mississippi. The escalating cycle of peaceful protest and brutal response, which culminated in the multiple bombings and killings of 1963, forced a hesitant administration to pursue a public accommodations bill in hopes of averting the demonstrations and riots that were embarrassing it domestically and around the globe. Even after the announcement of the drive for a new civil rights bill, activists understood that they had to keep the pressure on lest the pending legislation resemble the weak measures of recent years. When Martin Luther King declared in his "I Have A Dream" speech to the 1963 March on Washington that black Americans "can never be satisfied as long as our bodies, heavy with the fatigue of travel, cannot gain lodging in the motels of the highways and the hotels of the cities," there was no mistaking his reference. ${ }^{45}$

44. Delaware Code Ann. Tit. 24, § 1501; Louisiana Acts 1954 No. 194, § 1; Tennessee Code Ann. §62-710; Mississippi Code Ann. §2046.5 (1956 Supp.); Florida Statutes Ann. § 509.092 (1958 Supp.); Arkansas Act No. $226 \S 1$. Cited in Greenberg, Race Relations and American Law, 97, 419. On Alabama, see Senate Commerce Committee Report No. 872, 88th Congress, 2nd Session (1964), 10.

45. Taylor Branch, Parting the Waters: America in the King Years, 1954-63 (New York: Simon \& Schuster, 1988), chaps. 10-23; Taylor Branch, Pillar of Fire: America in the King Years, 1963-65 (New York: Simon \& Schuster, 1998), Pts. 1, 2; Chafe, Civilities and Civil Rights, 98-214; Thornton, Dividing Lines, 227-30, 239-53; Dittmer, Local People, 153-57, 165-69, 193-99; Mary L. Dudziak, Cold War Civil Rights: Race and the Image of American Democracy (Princeton: Princeton University Press, 2000), 152-248. 


\section{Innkeeper Law, the Commerce Clause, and the Civil Rights Act of 1964}

The Civil Rights Act of 1964 was an omnibus civil rights bill covering a number of areas, but in the context of the politics of the day, its basic innovation and primary importance both consisted in Title II, its section on public accommodations. In phrasing that closely resembled the Civil Rights Act of 1875, it outlawed discrimination in "any inn, hotel, motel ... any restaurant, cafeteria, lunchroom, lunch counter, soda fountain . . . any motion picture house, theater, concert hall, sports arena, stadium or other place of exhibition or entertainment." In order to accomplish this end, legislators both emphasized the human cost of discrimination against black travelers and revived the egalitarian potential of innkeeper and common carrier law. As part of the lawmaking process, Congress held hearings in order to establish the scope of the problem and identify the appropriate measures to be taken. The hearings lasted several weeks, occupied three separate committees, involved hundreds of witnesses (including political figures, civil rights activists, lawyers, labor union officials, representatives from religious groups, directors of professional organizations, educators, and private citizens), and produced thousands of pages of testimony and documentation regarding the difficulties, indignities, and perils facing black travelers. In the same way that the wording of the 1964 Act recalled its 1875 predecessor, the concern for the particular vulnerability of travelers that was expressed in these hearings echoed that which was evidenced in the eighteenth- and nineteenth-century statutes and treatises cited above. Although these findings were stripped from the final bill by southern senators, the committees published official reports that would be cited frequently by lawyers and judges during the litigation over the Act. Members of Congress were also clearly aware of the importance of the common law in supporting their claim of authority over public accommodations. The official report of the Senate Commerce Committee, for example, included an excursus on English and American innkeeper law that was directed at refuting objections based on property rights and constitutional limitations. After months of debate, careful parliamentary maneuvering, and the first-ever breaking of a southern filibuster on a civil rights bill, the Act was passed by Congress and signed into law in an evening ceremony on July 2, 1964. ${ }^{46}$

46. Civil Rights Act of 1964, 78 Stat. 241 (1964). The Act did not mention modes of transportation because these had already been officially desegregated by ICC order. 88th Congress, Senate Committee on Judiciary Published Hearing, CIS No. 88 S1592 (three parts); 88th Congress, House Committee on Judiciary Published Hearing, CIS No. 88 H2036 
Barely two hours later, Moreton Rolleston, an attorney representing the proprietors of a Georgia motel, filed a lawsuit challenging its constitutionality. Rolleston asserted that the Act must be declared unconstitutional for the same reason the Act of 1875 had been: the Fourteenth Amendment required state action to trigger federal enforcement, and the motel was a privately owned business. In another demonstration of the ongoing utility of classical liberal theory in sustaining discrimination, he reached for the same property-rights arguments that had been used decades before. Rolleston maintained that the "fundamental question . . . is whether or not Congress has the power to take away the liberty of an individual to run his business as he sees fit in the selection and choice of his customers," thereby reiterating the privatistic logic of the 1850 ruling in Commonwealth v. Mitchel. Rolleston alleged furthermore that the Act was unconstitutional under the Fifth and Thirteenth Amendments because it deprived his client of liberty and property without due process and forced him to involuntarily serve black customers. The task facing the government's lawyers was thus to avoid the 1883 Civil Rights Cases precedent and address doubts based on three Amendments; this required them to locate the authority for the Act under the commerce clause and revisit the legal status of travelers. ${ }^{47}$

In briefs filed by the Department of Justice and state solicitors general in Heart of Atlanta Motel v. United States, the need to protect black travelers was the key justification offered for the Civil Rights Act. The technical argument was that the Act properly drew its authority from the Constitution's commerce clause, but it is essential to note that the line of reasoning rested more upon the need to protect actual travelers than it did upon an economistic notion of disrupted trade. Solicitor General Archibald Cox's brief did open with a lengthy discussion of how discrimination in public

(four parts); 88th Congress, Senate Committee on Commerce Public Hearing, CIS No. 88 S1580-0, esp. 9-10, 22 (all Washington, D.C.: Government Printing Office, 1963, 1964). On the Civil Rights Act more generally, see Charles and Barbara Whalen, The Longest Debate: A Legislative History of the 1964 Civil Rights Act (Washington, D.C.: Seven Locks Press, 1985); Robert D. Loevy, To End All Segregation: The Politics of the Passage of the Civil Rights Act of 1964 (Lanham, Md: University Press of America, 1990); Robert D. Loevy, ed., The Civil Rights Act of 1964: The Passage of the Law That Ended Segregation (Albany: State University of New York Press, 1997).

47. Cortner, Civil Rights and Public Accommodations, 35-37; Brief of Appellant in Heart of Atlanta Motel v. United States, 16, 32-37, 51-58. It is not clear whether Rolleston had direct knowledge of Commonwealth v. Mitchel. He would have had access to the same indexes and treatises cited in this article, though his sparing use of citations (relative to the justice department) and the speed with which he filed suit suggest that he had not gone back for case-by-case reading. My point here involves shared logic rather than necessarily direct textual borrowing. For a detailed account of litigation against the Act, see Cortner, especially 90-96, 99-114. 
accommodations obstructed commerce in the South and nationally, but it was followed by an even longer argument regarding the burden placed on people. Cox pointed out that the Act had been motivated by "overwhelming evidence that discrimination by hotels and motels impedes interstate travel by Negroes, and interstate travel is, of course, a form of interstate commerce. The plain truth is that in many places lodging is simply not available to Negro travelers." He then proffered a thorough review of testimony before Congress, citing a senator's observation that black travelers "must draw up travel plans much as a general advancing across hostile territory" and reiterating the "strain," "uncertainty," and "humiliation and embarrassment" they faced on the road. In arguing that the federal government's jurisdiction also applied to travel within a single state, Cox asserted that establishing different rules for interstate and intrastate travel "would subject Negro travelers to the risks and burdens of being required to prove that they were engaged in an interstate journey," a requirement that "would itself be a form of humiliating discrimination, which would burden interstate travel scarcely less than the sort of racial discrimination which the Act seeks to eliminate." 48

State amicus curiae briefs were even more focused on the protection of travelers, placing greater emphasis on this need than on the economic importance of travel. The New York and California briefs declared travel to be "a hallmark of the American way of life" and "a basic and essential attribute of United States Citizenship." California's brief expressed concern for "the rights of California's citizens in their interstate travels," and while it did mention some economic reasons for travel, it emphasized the human element, noting that "commerce in people binds our nation together in a way that commerce in products alone could never do." The real issue was "the right of California's citizens to move freely among the several states," a right that required federal action because "California, acting alone, cannot adequately protect her citizens or facilitate their travel once they leave the state." The New York brief opened by declaring that while black people were "protected under the laws of this State ... their ability to move freely in certain other parts of the country for pleasure or business has been impeded by discrimination[..]" It referred to the "poignant testimony" offered in Congress regarding "the human problem of Negro families traveling by car, weary as they drive on, past vacancy signs at motels, until they reach a town or city where they have friends.” The Massachusetts brief noted that it had in 1865 been the first state to pass a public accommodations antidiscrimination law and referenced the plight of the black traveler with the observation that it was "obvious that many persons

48. Brief of Appellees in Heart of Atlanta v. U. S., 8-13, 38-39, 42-43, 53-54. 
of the discriminated-against minority will avoid traveling in areas where they expect to be humiliated and degraded[.]" The brief also emphasized the importance and legitimacy of applying Congress's commerce power not only to trade, but to travelers directly. While the means of travel and the modes of governance had certainly changed, the special attention to the needs of travelers would have been familiar to the American jurists of one hundred or two hundred years earlier. ${ }^{49}$

Innkeeper law was invoked to parry the claim that the Civil Rights Act violated the Fifth and Thirteenth Amendments. The Justice Department's brief defined inns as public and buttressed its argument by specifically emphasizing the long history of the innkeeper's duties: "A public inn is, of course, one of the most ancient and plainest examples of a business affected with a public interest." "The innkeeper," it argued, "has conventionally been subject, since long before the Bill of Rights was adopted, to the common-law duty to serve all travellers equally, without regard to personal preference, so long as he can accommodate them." These facts led to the conclusion that "the Fifth Amendment does not include freedom to discriminate against a traveler" and that therefore "the common-law duties of innkeepers is enough to answer appellant's claims under the Fifth Amendment[.]" Regarding the Thirteenth Amendment, the brief stated that existing state and federal public accommodations laws "codify and extend the common-law innkeeper rule, which of course long predated the ratification of the Thirteenth Amendment. Certainly, appellant cannot believe that the Amendment was intended to abrogate this common-law principle." In arguing that the Constitution must not be interpreted in such a way as to deprive travelers of the longstanding protections offered by the common law, Justice Department attorneys explicitly and intentionally revivified key aspects of the well-regulated society. ${ }^{50}$

The need to protect travelers and the law of innkeepers were also raised during oral arguments in the Heart of Atlanta case. In the initial hearing before a three-judge panel of the District Court in Georgia, Assistant At-

49. Brief of the Attorney General of the State of New York as Amicus Curiae in Support of Affirmance, 1, 3-10; Brief of the State of California as Amicus Curiae, 1, 4-8; Amicus Curiae Brief on Behalf of the Commonwealth of Massachusetts, 1, 16. This is not to say that economic arguments were not made in briefs before the Supreme Court, but rather that these points were secondary, made only after lengthy appeals to the need to protect black travelers.

50. Brief of Appellees, 56-59, 61. The New York State amicus brief invoked innkeeper law in the same context: "The Civil Rights Act of 1964 only deprives operators of public places catering to transients of the freedom to deny their accommodations to a segment of the public, a so-called freedom that innkeepers never had under the common law." State of New York as Amicus Curiae, 9-10. 
torney General Burke Marshall defended the Act not simply on the basis of interstate commerce, but on the fact of travel itself. He explained that it applied to all of the Heart of Atlanta Motel's guests regardless of whether they moved from state to state. "It means people that are moving," he explained, "it means that the hotel is, the hotel caters to transients. . . . It takes in people that usually come from some other place, but the some other place does not ... have to be shown to have been another state." In explaining the basis for the Act under the commerce power, he specified that a key justification was "simply the burden on Negro travelers." Rolleston, the motel's attorney, faced pointed questions about innkeeper law when he asserted that proprietors could turn customers away "for any reason we wanted." "Does the innkeeper traditionally have the same privilege?" asked one judge. "He had to take them all, did he not?" Rolleston was forced to concede the general point, but noted that because Georgia had passed a "statute [which] has changed the common law" to eliminate innkeepers' obligations, the motel was exempt from this requirement. ${ }^{51}$

The oral arguments before the Supreme Court made it even clearer that it was the need to protect travelers that triggered the federal government's power under the commerce clause. Solicitor General Cox stated explicitly that "the fact that the particular establishment affects transient guests tends to link it more closely than it would be otherwise linked to commerce, and therefore to bring it farther within the ambit of Federal regulation." Recognizing the importance of this linkage, Rolleston attempted a formalist argument by claiming that travelers should not be considered commerce at all. As it became clear that the justices were not being persuaded on this point and that the government was succeeding in making the burden on travelers the trigger for the commerce power, Rolleston resorted to arguing that black travelers in fact had no difficulty finding shelter. Because so many motels had desegregated already, he claimed, even if the Heart of Atlanta continued to refuse them service, there was no longer "any shortage of rooms in the United States for colored people to use." Rolleston, it seems, had concluded that the only way to save his case was through an outright denial of the vulnerability of black travelers. ${ }^{52}$

The Supreme Court's unanimous ruling in Heart of Atlanta Motel v. U.S.

51. Transcript of oral arguments, In the United States District Court for the Northern District of Georgia, 52, 62-66.

52. Oral argument transcript from Philip B. Kurland et al., eds., Landmark Briefs and Arguments of the Supreme Court of the United States: Constitutional Law (Washington, D.C.: University Publications of America, 1975-), v. 60, 15-16, 21-25, 44-53. Cox also made specific reference to the common law in refuting Rolleston's Thirteenth Amendment argument, observing that the motel's attorney was effectively claiming "that the AngloAmerican common law for centuries has subjected to slavery innkeepers, hackmen, carriers, 
upheld the Civil Rights Act of 1964 substantially on the basis of the need to protect travelers. The commerce clause provided the technical grounds for the ruling, but, as stated above, it is essential to recognize that the justices believed that it was the effect of segregation on actual travelers, and not simply on an abstracted commerce, that served as the trigger for the commerce power. The justices' discussion of "The Basis of Congressional Action" dealt almost exclusively with the plight of black wayfarers:

[Congressional] testimony included the fact that our people have become increasingly mobile, with millions of people of all races traveling from State to State; that Negroes in particular have been the subject of discrimination in transient accommodations, having to travel great distances to secure the same; that often they have been unable to obtain accommodations, and have had to call upon friends to put them up overnight ... and that these conditions had become so acute as to require the listing of available lodging for Negroes in a special guidebook which was itself "dramatic testimony to the difficulties" Negroes encounter in travel. ... We shall not burden this opinion with further details, since the voluminous testimony presents overwhelming evidence that discrimination by hotels and motels impedes interstate travel.

The justices rejected the notion that interstate commerce did not include travel and even set aside the importance of commerce itself. "Commerce among the states," they stated, "consists of intercourse and traffic between their citizens, and includes the transportation of persons and property. ... Nor does it make any difference whether the transportation is commercial in character." The justices also invoked the common law, confirming that "innkeepers, by the laws of all the States, so far as we are aware, are bound, to the extent of their facilities, to furnish proper accommodation to all unobjectionable persons who in good faith apply for them." They also observed that many states had enacted public accommodations laws that "but codify the common law innkeeper rule" and were thus persuaded to dismiss Fifth and Thirteenth Amendment objections to the new law. ${ }^{53}$ The character of travel also arose in the all-important matter of distinguishing Heart of Atlanta from the Civil Rights Cases ruling that had doomed the earlier civil rights law. The conditions under which the 1875 Act operated, the justices reasoned, had not been the same as in 1964: "Our populace had not reached its present mobility ... the conditions of transportation and commerce have changed dramatically, and we must apply those principles

wharfage men, ferriers, all kinds of other people holding themselves out to serve the public." See Kurland, 42.

53. Heart of Atlanta Motel v. United States (1964), 379 U.S. 241, 252-53, 256, 260 61. 
to the present state of commerce. The sheer increase in volume of interstate traffic alone would give discriminatory practices which inhibit travel a far greater impact upon the Nation's commerce than such practices had upon the economy of another day." 54 The fact of travel was, in sum, as close to twentieth-century jurists' understanding of civil rights law as it had been to that of their nineteenth-century counterparts. ${ }^{55}$

Legal protections of travelers were effective in securing equality. But this litigation strategy always existed in tension with the high ideals of the civil rights movement. At every stage of the struggle, demonstrators and judges objected to the way their protest and jurisprudential ideals were being reduced to crabbed formulations having less to do with the principle of equality than with narrow, cautious claims and legal technicalities. While civil rights activists were delighted with the Supreme Court's verdict in Morgan v. Virginia, some criticized the grounds of the decision: the Baltimore Afro-American, for example, expressed its disappointment that the case had been decided on the basis of the commerce power rather than the nobler ideal of equal rights. Members of the Senate openly questioned whether grounding the Civil Rights Act of 1964 on the commerce power rather than the Fourteenth Amendment was a timid stance that compromised America's commitment to equality; one senator from Vermont went so far as to append to the Commerce Committee's official report a 250-page brief boldly arguing that justice itself demanded the Act rest on the principle of equal protection. During the Supreme Court's

54. Ibid., 250-51. It is worth noting that travel was also a key issue in Katzenbach v. McClung, the companion case to Heart of Atlanta Motel, which dealt with the Civil Rights Act's applicability to a local barbecue restaurant far from any interstate thoroughfares and serving a local clientele, and therefore less directly implicated in interstate commerce. The Court's opinion cited the effect of restaurant segregation on travel by black people, calling attention to "an impressive array of testimony that discrimination in restaurants had a direct and highly restrictive effect upon interstate travel by Negroes," a situation that "obviously discourages travel and obstructs interstate commerce for one can hardly travel without eating." See Katzenbach v. McClung, 379 U.S. 294 (1964), 300.

55. The coming of the automobile was radically changing the physical and human geography of transportation in the first half of the twentieth century, a fact that (as Willard Hurst suggests in the quotation in note 2) likely influenced the development of laws regarding transportation, accommodation, and race: automobility allowed black people to travel without facing the daily humiliation of Jim Crow inherent in mass transit. See Welke, Recasting American Liberty, 376. While I agree that this change in transportation regime must have been important, the Court in Heart of Atlanta (at 256) seemed to suggest otherwise, citing an earlier ruling that: "The recent changes in transportation brought about by the coming of automobiles [do] not seem of great significance in the problem. People of all races travel today more extensively than in 1878, when this Court first passed upon state regulation of racial segregation in commerce. [It but] emphasizes the soundness of this Court's early conclusion in Hall v. DeCuir, 95 U.S. 485." 
deliberations over the constitutionality of the Act, there was active contention over the proper grounds for upholding it, with Justices Goldberg and Douglas particularly insistent on the issue of formal equality. Goldberg asserted that the question should be regarded openly as a moral one and at one point sent Douglas a note voicing his misgivings that defending the Act solely on the basis of the commerce clause made it seem "like hamburgers are more important than human rights." Both justices issued concurring opinions urging the application of the Fourteenth Amendment guarantee of equal rights. ${ }^{56}$

Protesters, legislators, attorneys, and jurists understood that legal challenges to segregation had to proceed according to the often arcane procedures of American law. As during Reconstruction, the legal system was the key point of articulation between locally based activism and nationwide reform-it was, in other words, the intermediating power of the law that allowed a single act of civil disobedience in Greensboro, North Carolina to hold the promise of changing the lives of black people in thousands of communities across the United States. Yet sometimes this legal process seemed to deny the ideals of the movement that had set it into motion, and thus the language of rights and equality and the legal protections of the traveler always coexisted uneasily in the quest for civil rights.

\section{Rethinking Civil Rights}

Historicizing the advent of equality in public accommodations reveals the complexity of the social, political, and legal traditions that lay behind it, compelling us to rethink the basic character of what we call civil rights. By closely examining changes in the regulation of public places, we can see clearly how seemingly abstract ideas were articulated in lived experience: how ideology became power in the form of law, and how specific legal constructions set the terms on which Americans confronted each other in everyday life. In particular, we come to understand why public accommodations held such a prominent place in civil rights history, and how legal regimes of travel became pivotal in securing equality for all. Civil rights in public accommodations were more than simply individually possessed

56. Barnes, Journey From Jim Crow, 50-51; 88th Congress, 2d Session, Senate, Report No. 872, "Civil Rights-Public Accommodations" Senate Commerce Committee, submitted February 10, 1964, and Report No. 872, Appendix A, by Senator Winston L. Prouty (Washington, D.C.: Government Printing Office, 1964); Papers of Earl Warren, Container No. 267, Case No. 515, 1964 Term, Bench Memo; Papers of William J. Brennan, Jr., Part I: 127, Case File No. 64-515; Papers of William O. Douglas, Container No. 1348. 
entitlements based on liberal notions of personal autonomy and formal equality; they were also predicated on a collectively defined public good and dependent upon corporative, premodern legal regimes that assumed personal vulnerability and asymmetrical relations of dependence and duty between travelers and their hosts. When black Americans and their allies protested against racial injustice, they invoked Enlightenment-inspired ideals of freedom and equality, making their claims all the more compelling for being in the familiar national tongue of liberty and natural rights. But when these ideals had to be put into practice-when the time came to draft civil rights legislation, move it through Congress, and defend it against legal challenge - the law's special protections for travelers became an indispensable legal basis for remedial action by the state.

This new interpretation also suggests the need for revisions to the standard account of the career of Jim Crow. The civil rights narrative usually begins with the Fourteenth Amendment's guarantee of equal protection, proceeds through the abandonment of racial justice in the "separate but equal" rule of Plessy v. Ferguson, continues with the re-establishment of a constitutional requirement of equality in Brown v. Board of Education, and concludes with the struggle for enforcement. This account is without a doubt valid on facts and interpretation. At the same time, though, it espouses a very particular view of the connection between racial justice and legal liberalism. Jim Crow is defined as state power in the service of racism, an unholy alliance which is only defeated by protests against an overreaching state and in favor of formal legal equality. As a result, liberal political ideology is implicitly made into the hero of the story and set forth as the source of progress in the quest for racial justice. But if we turn our gaze from state-sponsored discrimination to the putatively private variety practiced by innkeepers and other proprietors, the story looks very different. A revised account would begin with the privileges of travelers under the common law, continue with the role of these privileges in outlawing racial discrimination under the Civil Rights Act of 1875, move through the rights-inspired disavowal of national antidiscrimination law in the Civil Rights Cases, and conclude with the re-establishment of active federal protection by way of the Civil Rights Act of 1964 and Heart of Atlanta Motel v. U.S. This new account would offer a much-needed corrective by emphasizing the importance of premodern, common law rules in ending segregation outside the instrumentalities of the state; and by highlighting the fact that discrimination in public places was ended despite, not thanks to, the particular imperatives and priorities of liberal ideology. My purpose here is not to call for a wholesale replacement of the former civil rights narrative with the latter. I certainly do mean to say, however, that both 
are necessary for a proper understanding of the intricate and contradictory historical legacy of law, civil society, and liberalism. ${ }^{57}$

These findings also illuminate the dynamic interplay among political theories within American governance. The struggle for civil rights exposed a profound contradiction: political liberalism had generated demands that legal liberalism could not satisfy. The very idea of equal treatment under law was itself a product of classical liberal thought, yet it was liberal social theory that provided the surest ideological defense of private discrimination, and it was liberal legalism that furnished the means to obstruct possible remedies. This paradox could be resolved, and racial justice achieved, only through the reinterpretation and redeployment of centuries-old legal regimes that had previously lost favor but suddenly offered a hugely serviceable model of social citizenship and public authority. The political genealogy of the United States is thus revealed as far too complex to be encapsulated by linear narratives in which communitarian governance and customary codes of conduct are superseded by a rationalized rule of law and the liberal state. American ideas about justice transcend the universalistic and totalizing claims of liberalism because they display every sign of polyvalence, hybridity, and regular reinvention. Ultimately, then, this history of civil rights in public accommodations reminds us that however much modern civil society owes to the liberalism of the Enlightenment, it also rests upon a definitively premodern vision of the public good.

57. See, for example, Lawrence M. Friedman, A History of American Law (New York: Simon \& Schuster, 1973), 576-80; Harvard Sitkoff, The Struggle for Black Equality, 1954 1980 (New York: Hill and Wang, 1981); Kermit L. Hall, The Magic Mirror: Law in American History (New York: Oxford University Press, 1989), 322-27; Kermit L. Hall, William M. Wiecek, and Paul Finkelman, American Legal History: Cases and Materials (New York: Oxford University Press, 1991), 510-16; Michael J. Klarman, From Jim Crow to Civil Rights (New York: Oxford University Press, 2004). 